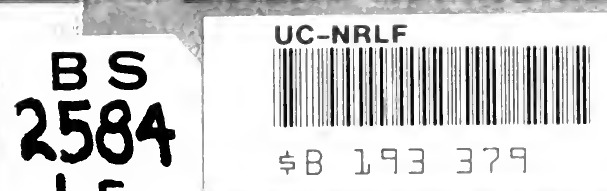

45
1913

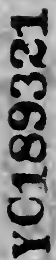




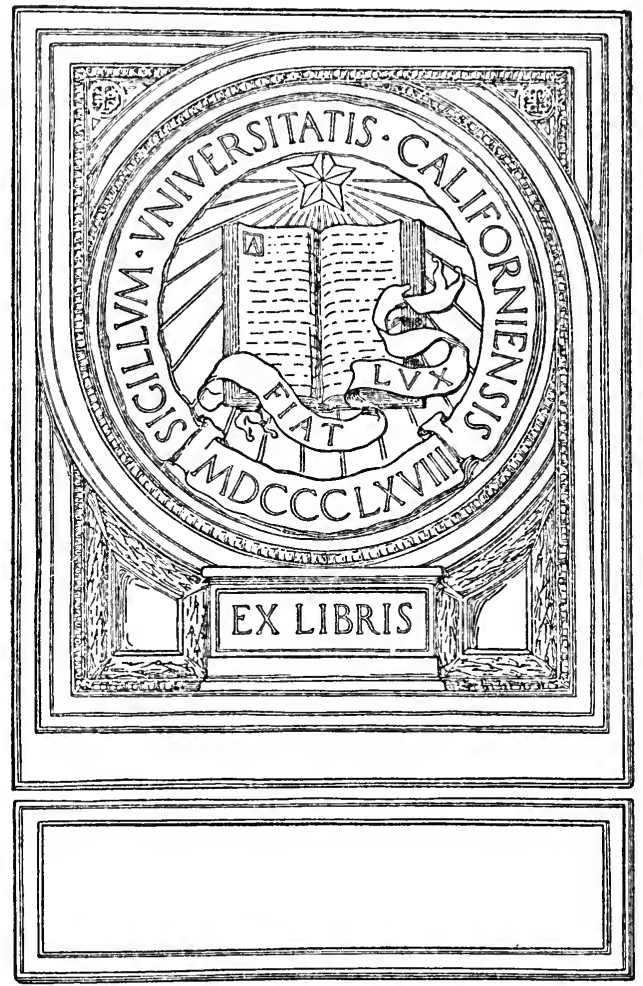


English=Lithuanian

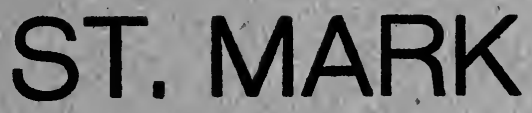

B. 


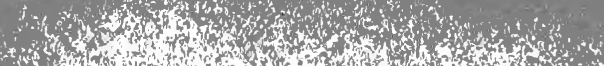

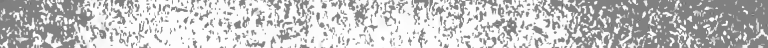

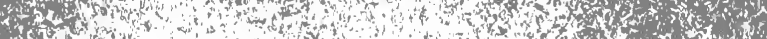
INos

Clex tro

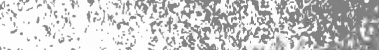

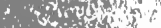

zitis

is 38 .

s.

$8(2+5)$

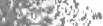

1025

$400 \%$

ates

ing

(a)

$3 \times x_{0}, 8$

ind

(8) 132

ats

ins

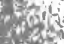

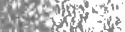

20ughas

astion

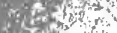

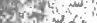

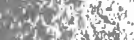

S 1 (4)

of

ints

soser.

sot

5. 1030.

sencisis

is fur the ?

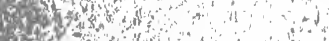

ind

$x-4+2 \times 2$

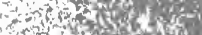

ing and

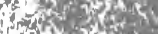

ard

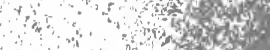

$\therefore \quad \cdots$

$10+30$

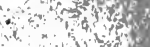

ats

40 a

in $x^{2}+4$

for ins

$30 x^{2}+4$

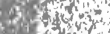

secty

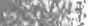

and

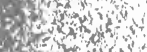

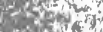

bot

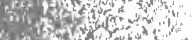

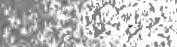

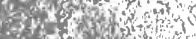

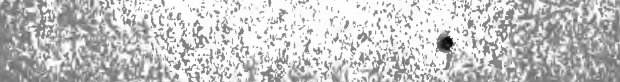

Fet

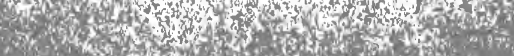

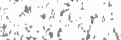

St

ations

$x_{0,4 i n}$

$3=3 x^{2}$

A

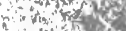

and

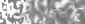

and in

$a^{2} x^{2}$

ar tont

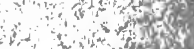

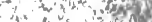

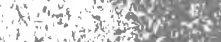

r on

sing

1

a d

inis on

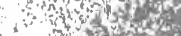

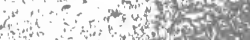

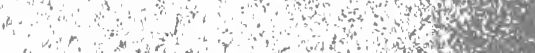

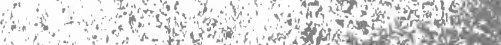

trits

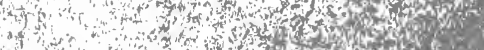

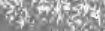




\title{
THE GOSPEL
}

\author{
ACCORDING TO \\ SAIN'T MARK.
}

\section{LONDON}

BRITISH AND FOREIGN BIBLE SOCIETY. 1913. 


\section{EVANGÉLIA}

ŠV. MARKOŠIAUS.

LONDONE

Britiškoji ir svetimuju žemių biblijų draugystẽ. 


\section{Digitized by the Internet Archive in 2007 with funding from Microsoft Corporation}


THE GOSPEL ACCORDING TO

\section{ST. MARK}

\section{CHAPTER I.}

TTHE beginning of the gospel 1 of Jesus Christ, the Son of God;

2 As it is written in the prophets, Behold, I send my messenger before thy face, which shall prepare thy way before thee. 3 The voice of one crying in the wilderness, Prepare ye the way of the Lord, make his paths straight. $4 \mathrm{John}$ did baptize in the wilderness, and preach the baptism of repentance for the remission of sins.

$5^{\circ}$ And there went out unto him all the land of Judæa, and they of Jerusalem, and were all baptized of him in the river of Jordan, confessing their sins.

6 And John was clothed with camel's hair, and with a girdle of a skin about his loins; and he did eat locusts and wild honey;

7 And preached, saying, There cometh one mightier than I after me, the latchet of whose shoes I am not worthy to stoop down and unloose.

$8 \mathrm{I}$ indeed have baptized you with water: but he shall baptize you with the Holy Ghost.

9 And it came to pass in those days, that Jesus came from $\mathrm{Na}$ zareth of Galilee, and was baptized of John in Jordan.
EVANGĖLIA ŠVENTO

MARKOŠIAUS.

\section{PERSKYRIMAS I.}

ČITA yra pradžia Evangėlios apie D Jėzų Kristų, Dievo sunų,

2 Kaipo parašyta yra prarakuose: ,„stai, aš siunčiu savo angielą pirm tavęs, kursai pagatavys tavo kelia pirm tavęs."

3 ,Yra balsas Dievo žodi sakančio pusčioje: taisykite kelią Viešpaties, lygius darykite jo takus."

4 Jonas buvo pusčioje, krikštijo ir apsakẻ krikštą prisivertimo ant grieku atleidimo.

5 Ir išèjo pas ji visa Žydų žemè, ir tie iš Jèruzalès, ir visi jo krikštydinos Jordane, išsipažindami savo griekus.

6 Bet Jonas aprẻdytas buvo verbludu plaukais, ir šikšnos diržu aplink savo strẻnas, ir valgè žogus bei laukini medu;

7 Ir pamokslą sakè, tarydamas: ateiti vienas paskui manę, tas drutesnis už manę, kurio ne esmi vertas, kad jam kloniočiaus, ir atriščiau dirželius jo kurpiụ.

8 Aš krikštiju jus vandenimi; ale jisai krikštys jus šventaja Dvase.

9 Ir nusidavè tuo čèsu, kad Jèzus atėjo iš Galilèos, iš Nazaret, ir krikštydinosi Jono Jordane. 
ST. MARK, I.

10 And straightway coming up out of the water, he saw the heavens opened, and the Spirit like a dove descending upon him :

11 And there came a voice from heaven, saying, Thou art my beloved Son, in whom I am well pleased.

12 And immediately the spirit driveth him into the wilderness.

13 And he was there in the wilderness forty days, tempted of Satan; and was with the wild beasts; and the angels ministered unto him.

14 Now after that John was put in prison, Jesus came into Galilee, preaching the gospel of the kingdom of God,

15 And saying, The time is fulfilled, and the kingdom of God is at hand : repent ye, and believe the gospel.

16 Now as he walked by the sea of Galilee, he saw Simon and Andrew his brother casting a net into the sea: for they were fishers.

17 And Jesus said unto them, Come ye after $m e$, and I will make you to become fishers of men.

18 And straightway they forsook their nets, and followed him.

19 And when he had gone a little farther thence, he saw James the son of Zebedee, and John his brother, who also were in the ship mending their nets.

20 And straightway he called them : and they left their father Zebedee in the ship with the hired servants, and went after him.

21 And they went into Caper-
EV. MARKOŠIAUS, I.

10 Ir tuojaus išẻjęs iš vandens išvydo dangų atsiverianti, ir Dvasę, kaip karveli, ant jo nusileidžiančią.

11 Ir tada balsas iš dangaus stojosi: Tu esi mano mielasis sunus, kuriuomi aš mėgstuos.

12 Ir tuojaus Dvasė ivarè ji i pusčią.

13 Ir buvo tenai pusčioje keturisdešimtis dienų, budamas šètono gundytas, ir buvo tarp žvèrių, ir angielai šlužijo jamui.

14 Bet kaip Jonas potam buvo paduotas, atėjo Jèzus i Galilèa, sakydamas evangẻlią apie karalystę Dievo,

15 Ir tarẻ: čèsas išsipildẻ, ir prisiartino karalystè Dievo; prisiverskite, ir tikẻkite evangẻliai.

16 Bet vaikščiodamas pas mares Galilèos, pamatè Simoną irEndrieju, jo broli, savo tinklus i mares beleidžiančiu; nẻs buvo žveju.

17 Ir Jèzus tarè jiemdviem: sekita manę; padarysu judu žmonių žvejais.

18 Tuojaus palikusiu savo tinklus sekẻ ji.

$19 \mathrm{Ir}$ iš čia maž toliaus nuẻjęs, pamatė Jokubą, sunu Zebedẻjaus, ir Joną, jo brolí, tinklą laive lopančiu; ir tuojaus vadino juodu.

20 Ir juodu, palikusiu savo tèvą Zebedejju laive su samdininkais, sekẻ ji.

21 Ir èjo i Kapernauma, ir 
naum: and straightway on the sabbath day he entered into the synagogue, and taught.

22 And they were astonished at his doctrine : for he taught them as one that had authority, and not as the scribes.

23 And there was in their synagogue a man with an unclean spirit; and he cried out,

24 Saying, Let us alone; what have we to do with thee, thou Jesus of Nazareth? art thou come to destroy us? I know thee who thou art, the Holy One of God.

25 And Jesus rebuked him, saying, Hold thy peace, and come out of him.

26 And when the unclean spirit had torn him, and cried with a loud voice, he came out of him. 27 And they were all amazed, insomuch that they questioned among themselves, saying, What thing is this? what new doctrine is this? for with authority com. mandeth he even the unclean spirits, and they do obey him.

28 And immediately his fame spread abroad throughout all the region round about Galilee.

29 And forthwith, when they were come out of the synagogue, they entered into the house of Simon and Andrew, with James and John.

30 But Simon's wife's mother lay sick of a fever, and anon they tell him of her.

31 And he came and took her by the hand, and lifted her up; and immediately the fever left her, and she ministered unto them. tuojaus sabatose jẻjęs jis $\mathfrak{i}$ mokyklą mokino.

22 Ir jie stebẻjosi jo pamokslo; nès jis mokino macniai, ir ne kaip raštemokịtieji.

23 Ir buvo jų mokykloje žmogus, nečystos dvasès varginamas, tas šaukè,

24 Sakydamas: ak! kągi mes su tavimi darbo turime, Jèzau iš Nazaret? tu atejjai mus išgaišinti. Zinau, kas tu esi; tu esi Dievo šventasis.

25 Ir Jèzus ji apdraudè, sakydamas: nutilk, ir išeik iš jo!

26 Ir nečystoji dvasè, plèšusi jị, šaukè didžiu balsu, ir išejo iš jo.

27 Ir nusigando visi, aža kitas kito klausinèjo tarydami: kas tai? koks tas naujas mokslas? Jis paliepia macniai nečystomsioms dvasèms, ir jos jo klauso.

$28 \mathrm{Ir}$ jo garsas išèjo greitai aplink i višą šalị Galilèos.

29 Ir tuojaus išẻję iš mokyklos, atėjo $\mathfrak{i}$ namus Simono ir Endriejaus, su Jokubu ir su Jonu.

30 Ir uošvė Simono gulèjo, sirgdama drugiu; ir tuojaus jam apie ją pasakè.

31 Ir jisai prièjęs prie jos, attiesẻ ją, ir laikè ją prie rankos, ir drugys ją tolydžiaus prastojo, ir ji šlužijo jiems. 
32 And at even, when the sun did set, they brought unto him all that were diseased, and them that were possessed with devils.

33 And all the city was gathered together at the door.

34 And he healed many that were sick of divers diseases, and cast out many devils; and suffered not the devils to speak, because they knew him.

35 And in the morning, rising up a great while before day, he went out, and departed into a solitary place, and there prayed.

36 And Simon and they that were with him followed after him.

37 And when they had found him, they said unto him, All men seek for thee.

38 And he said unto them, Let us go into the next towns, that I may preach there also: for therefore came I forth.

39 And he preached in their synagogues throughout all Galilee, and cast out devils.

40 And there came a leper to him, beseeching him, and kneeling down to him, and saying unto him, If thou wilt, thou canst make me clean.

41 And Jesus, moved with compassion, put forth his hand, and touched him, and saith unto him, I will; be thou clean.

42 And as soon as he had spoken, immediately the leprosy departed from him, and he was cleansed.

43 And he straitly charged him, and forthwith sent him away;

44 And saith unto him, See
32 Bet vakare, saulei nusileidus, atgabeno pas ji visokius negalinčius ir velnio varginamus.

33 Ir visas miestas susirinko pas duris.

34 Ir jis išgydė daug negalinčių, tuleropomis ligomis apsunkintu, ir išvarẻ daug velniu ir nedavè kalbèti velniams, nès jie pažino ji.

35 Ir rytmetyje, dar ne auštant, jis kèlęsi išèjo. Ir nuẻjęs Jèzus i pustą vietą, tenai meldèsi.

36 Ir Petras su esančiais pas ji, skubinosi paskui ji.

37 Ir radę ji, tarè jam: visi tavęs jëško.

$38 \mathrm{Ir}$ jis tarè jiems: eikime $\mathbf{i}$ artimiausiuosius miestus, kad ir tenai pamokslą sakyčiau; nės tam atẻjau.

39 Ir pamokslą sakẻ jų mokyklose visoje Galilèoje, ir išvarè velnius.

$40 \mathrm{Ir}$ atejo pas ji raupsuotas, tas atsiklaupęs prašé jo, sakydamas: jei nori, gali manę čystyti.

$41 \mathrm{Ir}$ Jẻzus pasigailèjęs ištiesẽ ranką, ir pakrutinęs ji tarè: noru, buk čystytas!

42 Ir jam taip sakant, tuojaus nuo jo raupsas atstojo, ir jis pastojo čystas.

43 Ir Jèzus ji apdraudęs, tuojaus ji pavaré nuo savęs, 44 Ir tarė jam: dabokis, idant 
ST. MARK, I. II.

thou say nothing to any man : but go thy way, shew thyself to the priest, and offer for thy cleansing those things which Moses commanded, for a testimony unto them.

45 But he went out, and began to publish it much, and to blaze abroad the matter, insomuch that Jesus could no more openly enter into the city, but was without in desert places: and they came to hin from every quarter.

\section{CHAPTER II.}

$A \mathrm{ND}$ again he entered into $\mathrm{Ca}-$ $A$ pernaum after some days; and it was noised that he was in the house.

2 And straightway many were gathered together, insomuch that there was no room to receive them, no, not so much as about the door: and he preached the word unto them.

3 And they come unto him, bringing one sick of the palsy, which was borne of four.

4 And when they could not come nigh unto him for the press, they uncovered the roof where he was: and when they had broken it up, they let down the bed wherein the sick of the palsy lay.

5 When Jesus saw their faith, he said unto the sick of the palsy, Son, thy sins be forgiven thee.

6 But there were certain of the scribes sitting there, and reasoning in their hearts,

7 Why doth this man thus speak blasphemies? who can forgive sins but God only?

8 And immediately when Jesus
EV. MARKOŠIAUS. I. II.

niekam tai ne sakytumbei, bet eik, ir pasirodyk kunigui, ir apieravok už savo apčystijimą, ką Maižěšius liepęs yra, ju apliudymui.

45 Bet jis išèjęs, pradẻjo daug apie tai sakyti, ir išplatino tą nusidavimą, taipo, kad jis ne galèjo žmonèms bematant eiti i miestą, bet buvo lauke pustose vietose, ir jie atẻjo pas ji iš visu kampu.

\section{PERSKYRIMAS II.}

TR po keliu dienu jis vèl parẻjo i Kapernaumą, ir žmonès patyrè, esanti namieje.

2 Ir tuojaus taip daug susiẹjo, kad ne sutilpo nei lauke pas duris; ir jis sakẻ jiems žodị.

3 Ir atèjo pas ji keli, tie atgabeno kaulliga sergantị, keturiụ nešamą.

4 Ir kaip ne galèjo ji prieiti dèl žmonių, praplēšé stoga, kur jis buvo, ir tą atdenge nuleido lovą, kurioje kaulliga sergąsis gulèjo.

5 BetJèzus, règėdamas jų tikẻjimą, tarẻ kaulliga sergančiamui: mano sunau, atleisti tau yra tavo griekai. 6 Bet buvo keli raštemokịtuju; ; tie čia sẻdẻdami dumojo savo širdyje:

7 Kaip šisas toki Dievo bluznijimą kalbą? kas gal griekus atleisti, kaip tikt vienas Dievas?

8 Ir Jèzus tuojaus numanẻ savo 
ST. MARK, II.

perceived in his spirit that they so reasoned within themselves, he said unto them, Why reason ye these things in your hearts?

9 Whether is it easier to say to the sick of the palsy, Thy sins be forgiven thee; or to say, Arise, and take up thy bed, and walk?

10 But that ye may know that the Son of man hath power on earth to forgive sins, (he saith to the sick of the palsy,)

$11 \mathrm{I}$ say unto thee, Arise, and take up thy bed, and go thy way into thine house.

12 And immediately he arose, took up the bed, and went forth before them all; insomuch that they were all amazed, and glorified God, saying, We never saw it on this fashion.

13 And he went forth again by the sea side; and all the multitude resorted unto him, and he taught them.

14 And as he passed by, he saw Levi the son of Alphæus sitting at the receipt of custom, and said unto him, Follow me. And he arose and followed him.

15 And it came to pass, that, as Jesus sat at meat in his house, many publicans and sinners sat also together with Jesus and his disciples: for there were many, and they followed him.

16 And when the scribes and Pharisees saw him eat with pub. licans and sinners, they said unto his disciples, How is it that he eateth and drinketh with pub. licans and sinners?

17 When Jesus heard it, he saith unto them, They that are whole have no need of the physician, but
EV. MARKOŠIAUS, II.

dvasẻje, juos taip savyje dumojant, ir taré jiems: ką tai dumojate savo širdyje?

9 Kas pigiaus yra, tarti kaulliga sergančiamui: atleisti tau yra tavo griekai, arba: kelkis, imk savo patalą, ir vaikščiok?

10 Bet kad zinotumbite, žmogaus Suny turinti maci ant žemės, atleisti griekus, tarẻ kaulliga sergančiamui:

11 Sakau tau: kelkis, imk savo patala, ir eik namon!

12 Ir jis tuojaus atsikèlęs ir èmęs savo patalą, išèjo po akiu visu, taip, kad visi nusigando, ir garbino Dieva, sakydami: mes toktai dar niekadai ne mateme.

13 Ir jis išèjo vèl pas mares, ir visi zmonès atejo pas $\mathrm{ji}$, ir jis mokino juos.

14 Ir praeidamas Jèzus pamatè Lèvị, sunu Alpèjaus, sẻdinti prie muito, ir tarè jam: sek manę. Ir jis kèlęsi sekẻ ji.

15 Ir nusidavè, Jézui be sẻdint už stalo jo namuose, daug muitininku ir griekininku susèdo už stalo su Jèzumi ir su jo mokịtiniais. Nès daug tụ buvo, kurie ji sekè.

16 Ir raštemokịtieji bei Parizẻušiai matydami, ji valgant su muitininkais ir griekininkais, tarè jo mokịtiniams: dèl ko jisai valgo ir geria su muitininkais ir griekininkais?

17 Tai Jèzus išgirdęs tarẻ jiems: drutieji ne privalo liekoriaus, bet ligonys. Aš atèjau vadinti grieki- 
ST. MARK, II.

they that are sick: I came not to call the righteous, but sinners to repentance.

18 And the disciples of John and of the Pharisees used to fast : and they come and say unto him, Why do the disciples of John and of the Pharisees fast, but thy disciples fast not?

19 And Jesus said unto them, Can the children of the bridechamber fast, while the bridegroom is with them? as long as they have the bridegroom with them, they cannot fast.

20 But the days will come, when the bridegroom shall be taken away from them, and then shall they fast in those days.

21 No man also seweth a piece of new cloth on an old garment: else the new piece that filled it up taketh away from the old, and the rent is made worse.

22 And no man putteth new wine into old bottles: else the new wine doth burst the bottles, and the wine is spilled, and the bottles will be marred: but new wine must be put into new bottles.

23 And it came to pass, that he went through the corn fields on the sabbath day; and his disciples began, as they went, to pluck the ears of corn.

24 And the Pharisees said unto him, Behold, why do they on the sabbath day that which is not lawful?

25 And he said unto them, Have ye never read what David did, when he had need, and was an hungred, he, and they that were with him?

26 How he went into the house
EV. MARKOŠIAUS, II.

ninkus prisivertimop, o ne teisiuosius.

18 Ir mokịtiniai Jono bei Parizėušiu daug pastnikavo; ir atẻje keli, tarè jam: kodèl mokịtiniai Jono ir Parizèušiu pastnikauja, o tavo mokitiniai ne pastnikauja?

19 Ir Jèzus tarẻ jiems: kaip gal svodbininkai pastnịkauti, jaunikiui pas juos esant? kol jaunikis pas juos yra, jie ne gal pastnikauti.

20 Bet ateis tas čèsas, kad nuo ju bus atimtas jaunikis; tai jie pastnikaus.

21 Nieks ne uždeda lopą naujo milo ant seno rubo; nès naujasis lopas nuplyšta nuo senojo, ir skylẻ didesnè pastoja.

22 Ir nieks nepila šviežy vyną i senus rykus, šeip šviežusis vynas išplaišina rykus, ir vynas išteka, ir rykai pagenda; bet šviežu vyną i naujus rykus reikia pilti.

23 Ir nusidavè, jam einant sabatoje per javus, pradejjo jo mokitiniai be eidami varpas traukyti.

24 Ir Parizėušiai tarẻ jam: štai, dabok, ka daro tavo mokịtiniai sabatoje, kas ne vale?

$25 \mathrm{Ir}$ jis tarẻ jiems: argi niekados ne skaitėte, ka Dovidas daré, kaip jis pristoko ir išalkęs buvo, su esančiaisiais pas ji?

26 Kaip jis èjo i Dievo namus 
ST. MARK, II. III.

of God in the days of Abiathar the high priest, and did eat the shew. bread, which is not lawful to eat but for the priests, and gave also to them which were with him?

27 And he said unto them, The sabbath was made for man, and not man for the sabbath :

28 Therefore the Son of man is Lord also of the sabbath.

\section{CHAPTER III.}

$A \mathrm{ND}$ he entered again into the A synagogue; and there was a man there which had a withered hand.

2 And they watched him, whether he would heal him on the sabbath day; that they might accuse him.

3 And he saith unto the man which had the withered hand, Stand forth.

4 And he saith unto them, Is it lawful to do good on the sabbath days, or to do evil? to save life, or to kill? But they held their peace.

5 And when he had looked round about on them with anger, being grieved for the hardness of their hearts, he saith unto the man, Stretch forth thine hand. And he stretched it out: and his hand was restored whole as the other.

6 And the Pharisees went forth, and straightway took counsel with the Herodians against him, how they might destroy him.

7 But Jesus withdrew himself with his disciples to the sea: and a great multitude from Galilee followed him, and from Judæa,

8 And from Jerusalem, and from Idumæa, and from beyond Jor-
EV. MARKOŠIAUS, II. III.

čèse Abjataro, vyriausiojo kunigo, ir valgè šventasias duonas, kurias niekam ne derèjo valgyti, kaip tikt kunigams, o jis dave ir tiems, pas ji esantiems.

$27 \mathrm{Ir}$ jis sakẻ jiems: sabata dèl žmogaus leista, o ne žmogus dèl sabatos.

28 Taigi žmogaus Sunus ir sabatos Viešpats yra.

\section{PERSKYRIMAS III.}

TR jis vèl èjo i mokyklą. Ir buvo čia žmogus, turis padžiuvusia. ranką.

2 Ir jie tykojo jo, bau jis ji sabatoje gydysiąs, kad priežasti ant jo gautu.

3 Ir tarè žmogui, turinčiam padžiuvusiąją ranką: čia stokis.

4 Ir tarè jiems: ar reikia sabatoje gero daryti, ar pikto? ar gyvasti išlaikyti, ar nužavinti? bet jie tylèjo.

5 Ir paeiliumi ant ju pažiurejjo supykęs, ir smutnijosi dèlei ju širdies kietumo, ir sakè tam žmogui: ištiesk savo ranką. Ir jis ištiesė ją; ir jo ranka jam sveika pastojo, kaip ir kita.

6 Ir Parizẻušiai išèje tuojaus sudumè su Erodo tarnais prieš ji, kaip ji nužavintų.

7 Bet Jẻzus su savo mokitiniais šalin èjo pas mares, ir daug žmonių ji sekè iš Galilèos ir iš Žydų žemès,

$8 \mathrm{Ir}$ iš Jèruzalès, ir iš Idumèos, ir iš anos šalies Jordano, ir tuc, 
ST. MARK, III.

dan; and they about Tyre and Sidon, a great multitude, when they had heard what great things he did, came unto him.

9 And he spake to his disciples, that a small ship should wait on him because of the multitude, lest they should throng him.

10 For he had healed many; insomuch that they pressed upon him for to touch him, as many as had plagues.

11 And unclean spirits, when they saw him, fell down before him, and cried, saying, Thou art the Son of God.

12 And he straitly charged them that they should not make him known.

13 And he goeth up into a mountain, and calleth unto him whom he would : and they came unto him.

14 And he ordained twelve, that they should be with him, and that he might send them forth to preach,

15 And to have power to heal sicknesses, and to cast out devils : 16 And Simon he surnamed Peter;

17 And James the son of Zebedee, and John the brother of James; and he surnamed them Boanerges, which is, The sons of thunder:

18 And Andrew, and Philip, and Bartholomew, and Matthew, and Thomas, and James the son of Alphæus, and Thaddæus, and Simon the Canaanite,

19 And Judas Iscariot, which also betrayed him : and they went into an house.

20 And the multitude cometh to-
EV. MARKOŠIAUS. III.

kurie gyvena aplink Tyru ir Sidoną, didè daugybẻ girdinčiųju jo darbus atėjo pas ji.

9 Ir jis sakè savo mokitiniams, kad laiveli jam laikytu gatavą dèl žmonių, jeib ji ne spaustų.

10 Nès jis daug jų gydè, taip, aža pulte ant jo puolè visi vargintieji, kad ji pakrutintu.

11 Ir dvasės nečystos, ji pamačiusios, atsiklaupẻ ir šaukè, sakydamos: tu esi Dievo Sunus.

$12 \mathrm{Ir}$ jis jas aštriai apdraudè, idant ji ne apreikštu.

13 Ir jis užèjęs ant kalno, vadino pas savę, kurius norejjo, ir tie atėjo pas ji.

$14 \mathrm{Ir}$ jis istatè anus dvylika, kad su juomi buty, ir kad jis juos išsiųstų, apsakyti Dievo žodí;

15 Ir kad turètu maci, išgydyti ligas ir velnius išvaryti.

16 Ir davè Simonui vardą Petro;

17 Ir Jokuba, sunu Zebedèjaus, ir Joną, broli Jokubo; ir davè jiemdviem varda Bneargem, tai musų žodžiu, perkuno vaikai.

18 Ir Endrieju, ir Pilipa, ir Baltramiejŭ, ir Matèošių, ir Tamošiu, ir Jokubą, sunų Alpèjaus, ir Tadèušą, ir Simoną Kananytą,

19 Ir Judošiu Iškariotą, kursai ji išdavè.

20 Ir jiems parẻjus namon, vèl 
ST. MARK, III.

gether again, so that they could not so much as eat bread.

21 And when his friends heard of it, they went out to lay hold on him : for they said, $\mathrm{He}$ is beside himself.

22 If And the scribes which came down from Jerusalem said, He hath Beelzebub, and by the prince of the devils casteth he out devils.

23 And he called them unto him, and said unto them in parables, How can Satan cast out Satan?

24 And if a kingdom be divided against itself, that kingdom cannot stand.

25 And if a house be divided against itself, that house cannot stand.

26 And if Satan rise up against himself, and be divided, he cannot stand, but hath an end.

27 No man can enter into a strong man's house, and spoil his goods, except he will first bind the strong man; and then he will spoil his house.

28 Verily I say unto you, All sins shall be forgiven unto the sons of men, and blasphemies wherewith soever they shall blaspheme :

29 But he that shall blaspheme against the Holy Ghost hath never forgiveness, but is in danger of eternal damnation :

30 Because they said, $\mathrm{He}$ hath an unclean spirit.

31 I There came then his breth. ren and his mother, and, standing without, sent unto him, calling him.

32 And the multitude sat about
EV. MARKOS̃IAUS, III.

žmonès susirinko, taip, kad nei vietos ne turèjo valgyti.

21 Ir kaip tai girdèjo aplink ii esantieji, išejo jie, ji laikyti; nes jie tarè: jis iš umo išeis.

22 Bet raštemokitieji, kurie buvo atẻję iš Jèruzalès, sakè: jis tur Beẻlzèbubą, ir per vyriausiaji velnių jis išvaro velnius.

23 Ir jis suvadinęs juos kalbejjo jiems prilyginimuose: kaip gal šètonas šetoną išvaryti?

24 Kad kokia karalystè pati tarp savęs ne sutinka, tai ji ne gal išsilaikytis.

25 Ir kad namai patys tarp savęs ne sutinka, tai jie ne gal išsilaikytis.

26 Taigi, jei šètonas pats prieš savę keliasi, ir su savimi ne sutinka, tai jis ne gal išsilaikytis, bet tur suteškèti.

27 Nieks ne gal stipriojo namus užpulti ir jo naudą išplèšti, jei ne pirma stiprujij suriša, ir potam jo namus išplèšia.

28 Iš tiesos sakau jums: visi griekai žmoniu vaikams atleidžiami, a ir Dievo bluznijimai, kuriais Dievą bluznija;

29 Bet kursai bluznija šventają Dvasę, tas ne gaun atleidimo amžinai, bet kaltas yra amžinojo sudo.

30 Nès jie sakè: Jis tur nečystą dvasę.

$31 \mathrm{Ir}$ atéjo jo motyna ir jo broliai; ir stovèdami lauke, nusiunte pas $\mathrm{ji}$, ir vadindino $\mathrm{ji}$.

32 Ir žmonès sẻdèjo aplink ji, 
ST. MARK, III. IV.

him, and they said unto him, Behold, thy mother and thy brethren without seek for thee.

33 And he answered them, saying, Who is my mother, or my brethren?

34 And he looked round about on them which sat about him, and said, Behold my mother and my brethren!

35 For whosoever shall do the will of God, the same is my brother, and my sister, and mother.

\section{CHAPTER IV.}

$\mathrm{ND}$ he began again to teach by $A$ the sea side : and there was gathered unto him a great multitude, so that he entered into a ship, and sat in the sea; and the whole multitude was by the sea on the land.

2 And he taught them many things by parables, and said unto them in his doctrine,

3 Hearken; Behold, there went out a sower to sow:

4 And it came to pass, as he sowed, some fell by the way side, and the fowls of the air came and devoured it up.

5 And some fell on stony ground, where it had not much earth; and immediately it sprang up, because it had no depth of earth :

6 But when the sun was up, it was scorched; and because it had no root, it withered away.

7 And some fell among thorns, and the thorns grew up, and choked it, and it yielded no fruit. 8 And other fell on good ground, and did yield fruit that sprang up
EV. MARKOŠIAUS, III. IV.

ir tarè jam: štai, tavo motyna ir tavo broliai lauke klausia tavęs.

33 Ir jis jiems atsakè, tarydamas: kas mano motyna, ir kas mano broliai?

$34 \mathrm{Ir}$ paeiliumi ant mokitinių, kurie aplink ji sẻdẻjo, pažiurèjęs, tarè: štai, tie mano motyna ir mano broliai.

35 Nès darąsis Dievo valę, tas yra mano brolis, ir mano sesuo ir mano motyna.

\section{PERSKYRIMAS IV.}

TR jis pradejjo ve̊l mokiti prie 1 marių; ir susirinko pas ji daug žmonių, taip, kad jis turèjo jžžengti i laiva, ir sèdèti ant vandens, ir visi žmonès stovèjo ant žemės pas mares.

2 Ir jis ilgai Dievo žodi sakẻ per prilyginimus. Ir savo pamoksle sakè jis jiems:

3 Klausykitès: štai, išẻjo sẻjęjas sèti.

4 Ir nusidavè, jam be sẻjant, keli grudai puolè pas kelią; tai paukščiai dangaus atlèkę sulesẻ tus.

5 Kiti vèl puolè $i$ akmenynę: kur ne daug žemès buvo, ir tuojaus išdygo, todèl, kad ne turèjo gilios žemès.

6 Bet saulei užtekejjus, pavyto, ir ne turẻdami šaknies, padžiuvo.

7 Ir kiti puolè tarp erškéčių; ir erškéčiai per viršu augo, ir nusmelkẻ tus, ir nenešè vaisiaus.

$8 \mathrm{Ir}$ kiti puolè i gerą žemę, ir vaisiu nešè tarpstanti, ir atnešẻ 
and increased; and brought forth, some thirty, and some sixty, and some an hundred.

9 And he said unto them, He that hath ears to hear, let him hear.

10 And when he was alone, they that were about him with the twelve asked of him the parable.

11 And he said unto them, Unto you it is given to know the mystery of the kingdom of God : but unto them that are without, all these things are done in parables:

12 That seeing they may see, and not perceive; and hearing they may hear, and not understand; lest at any time they should be converted, and their sins should be forgiven them.

13 And he said unto them, know ye not this parable? and how then will ye know all parables?

14 Tा The sower soweth the word. 15 And these are they by the way side, where the word is sown; but when they have heard, Satan cometh immediately, and taketh. away the word that was sown in their hearts.

16 And these are they likewise which are sown on stony ground; who, when they have heard the word, immediately receive it with gladness;

17 And have no root in themselves, and so endure but for a time : afterward, when affliction or persecution ariseth for the word's sake, immediately they are offended.

18 And these are they which are sown among thorns; such as hear the word,

19 And the cares of this world, and the deceitfulness of riches, kiti trisdešimteropa, ir kiti šešisdešimteropa, ir kiti šimteropą.

9 Ir jis sakẻ jiems: kas tur ausiy klausyti, tas te klauso.

10 Ir jam vienam be esant, klause̊ ji tie, kurie pas ji buvo su anais dvylika, apie tą prilyginimą.

$11 \mathrm{Ir}$ jis atsakè jiems: jums duota, žinoti paslëptines karalystẻs Dievo; bet tiems, kurie lauke, vislab sakoma per prilyginimus,

$12 \mathrm{Kad}$ atviromis akimis regètu, ir tikt ne išpažintu, ir girdinčiomis ausimis girdètu, ir tikt ne išmanytų; jeib ne kartunta prisiverstu, ir ne butu jiems atleisti ju griekai.

13 Ir tarè jiems: ar ne išmanote tą prilyginimą? kaipogi išmanysite visus kitus prilyginimus?

14 Sejjèjas sẻja žodị.

15 Bet kurie pas kelia, tie yra, kuriems žodis sèjamas yra, ir kad jie tą girdèję, tai tuojaus ateina šètonas, ir atima žodi, isètąji ju širdyje.

16 Taipojau ir tie, kurie $i$ akmenynę pasèti, tie yra, kurie girdèję žodi, tuojaus tą su džiaugsmu priima,

17 Ir ne tur šaknies savyje, bet yra lyg oras persimainąsis; kad randasi bèda, arba persekinéjimas dèl žodžio, tai jie tuojaus pasipiktina.

18 Ir kurie tarp erškèčiu pasėti, tie yra, kurie klausos žodžio;

19 Ir rupestis šio svieto, ir viliojantiji bagotystè, ir daug kitu gei- 
ST. MARK, IV.

and the lusts of other things entering in, choke the word, and it becometh unfruitful.

20 And these are they whtch are sown on good ground; such as hear the word, and receive it, and bring forth fruit, some thirtyfold, some sixty, and some an hundred.

21 If And he said unto them, Is a candle brought to be put under a bushel, or under a bed? and not to be set on a candlestick?

22 For there is nothing hid, which shall not be manifested; neither was any thing kept secret, but that it should come abroad.

23 If any man have ears to hear, let him hear.

24 And he said unto them, Take heed what ye hear: with what measure ye mete, it shall be measured to you : and unto you that hear shall more be given.

25 For he that hath, to him shall be given : and he that hath not, from him shall be taken even that which he hath.

26 I And he said, So is the king dom of God, as if a man should cast seed into the ground;

27 And should sleep, and rise night and day, and the seed should spring and grow up, he knoweth not how.

28 For the earth bringeth forth fruit of herself; first the blade, then the ear, after that the full corn in the ear.

29 But when the fruit is brought forth, immediately he putteth in the sickle, because the harvest is come.

30 I And he said, Whereunto
EV. MARKOŠIAUS, IV.

dulių užeina, ir nusmelkia žodị, ir pasiliekti be vaisiaus.

20 Ir kurie i gerą žemę sèti, tie yra, kurie klausos žodžio, ir tą priima, ir atneš vaisių, kits trisdešimteropą, ir kits šešisdešimteropa, ir kits šimteropą.

$21 \mathrm{Ir}$ jis sakẻ jiems: argi uždega kas žvakę, kad tą pastatytų po ketvirčiu, arba po stalu? ne, bet kad tą ant liktoriaus uždètų.

22 Nès nieko niera paslèpta, kas ne butų atdengta,ir nieko uždengta, kas ne butų apreikšta.

23 Kas tur ausių klausyti, tas te klauso!

$24 \mathrm{Ir}$ jis sakẻ jiems: dabokite, ką girdite. Kokiu saiku jus seikiate, tokiu bus jums vèl atseikèta, ir bus jums dar pridèta, kurie tai girdite.

25 Nės turinčiamjam duodama, o neturinčiamjam atimama ir tai, ką tur.

26 Ir jis sakè: tokia yra karalystè Dievo, lyg kaip kad žmogus įberia sẻklą i žemę;

27 Ir miegti, ir keliasi diena ir naktị, ir sèkla išdygsta, ir auga jam nežinant.

28 (Nẻs žemẻ iš savęs pirma neša želmeni, potam varpas, paskui brendusi kvieti varpose.)

29 Bet kad atnešusi vaisių, tai tuojaus jis nusiunčia piautuvus; nès piutis priẻjo.

30 Ir jis sakè: kam prilygįsime 
shall we liken the kingdom of / karalyste Dievo? arba kokiu priGod? or with what comparison shall we compare it?

31 It is like a grain of mustard seed, which, when it is sown in the earth, is less than all the seeds that be in the earth :

32 But when it is sown, it groweth up, and becometh greater than all herbs, and shooteth out great branches; so that the fowls of the air may lodge under the shadow of it.

33 And with many such parables spake he the word unto them, as they were able to hear $i t$.

34 But without a parable spake he not unto them: and when they were alone, he expounded all things to his disciples.

35 And the same day, when the even was come, he saith unto them, Let us pass over unto the other side.

36 And when they had sent away the multitude, they took him even as he was in the ship. And there were also with him other little ships.

37 And there arose a great storm of wind, and the waves beat into the ship, so that it was now full.

38 And he was in the hinder part of the ship, asleep on a pillow : and they awake him, and say unto him, Master, carest thou not that we perish?

39 And he arose, and rebuked the wind, and said unto the sea, Peace, be still. And the wind ceased, and there was a great calm.

40 And he said unto them, Why

37 Ir pasikèlè didis umaras vẻjo, ir vilnys mušè i laivą, taip, kad laivas pilnas vandens prisipylé.

$38 \mathrm{Ir}$ jis užgalyje laivo miegojo ant priegalvio, ir jie pabudino $\mathrm{ji}$, sakydami jam: Mokitojau, ar nieko ne atboji, kad mes prapuolame?

39 Ir jis atsikèlęs apdraudè vẻją, ir tarè marèms: nutilk ir buk tyka! Ir liovèsi vẻjas ir didei tyka pastojo.

40 Ir jis tarẻ jiems: kodèl taip 
ST. MARK, IV. V.

are ye so fearful? how is it that ye have no faith?

41 And they feared exceedingly, and said one to another, What manner of man is this, that even the wind and the sea obey him?

\section{CHAPTER V.}

$A$ ND they came over unto the $A$ other side of the sea, into the country of the Gadarenes.

2 And when he was come out of the ship, immediately there met him out of the tombs a man with an unclean spirit,

3 Who had his dwelling among the tombs; and no man could bind him, no, not with chains:

4 Because that he had been often bound with fetters and chains, and the chains had been plucked asunder by him, and the fetters broken in pieces: neither could any man tame him.

5 And always, night and day, he was in the mountains, and in the tombs, crying, and cutting himself with stones.

6 But when he saw Jesus afar off, he ran and worshipped him,

7 And cried with a loud voice, and said, What have I to do with thee, Jesus, thou Son of the most high God? I adjure thee by God, that thou torment me not.

8 For he said unto him, Come out of the man, thou unclean spirit.

9 And he asked him, What is thy name? And he answered, saying, My name is Legion: for we are many.
EV. MARKOŠIAUS, IV. V.

bijotės? kaipogi ne turite tikèjimo?

41 Ir jie didei bijojos ir sakè kits kitam: kas tasai? nès vèjas ir marès jo klauso.

\section{PERSKYRIMAS V.}

TR jie atẻjo anašal marių, i šali Gadarènų.

2 Ir kaip jis išèjo iš laivo, tuojaus jam priešais atẻjo žmogus iš kapų, dvasės nečystos pristotas,

3 Kursai laikẻsi kapuose. Ir nieks ji ne galejjo surišti, nei lencugais.

4 Nès tankiai buvo pančiais ir lencugais surištas, ir jis lencugus buvo sutraukęs, ir pančius sudaužęs, ir nieks ji ne galèjo suvaldyti.

5 Ir jis buvo visučès, dieną ir nakti, ant kalnu ir kapuose, šaukdamas ir akmenimis besimušdamas.

6 Bet Jèzu iš tolo pamatęs, jis pribėgo. ir atsiklaupęs didžiu balsu šaukè, tarydamas:

7 Ką turu darbo su tavimi, Jèzau, sunau Dievo, Aukščiausiojo? prisakau tau prie Dievo, kad manę ne vargintumbei!

8 Bet jis jam sakè: išeik, tu nečystoji dvasè, iš to žmogaus.

9 Ir jis klausé jo: kuo vardu esi? Ir jis atsakydamas tarẽ: mano vardas yra lègionas; nès musu daug yra. 
ST. MARK, V.

10 And he besought him much that he would not send them away out of the country.

11 Now there was there nigh unto the mountains a great herd of swine feeding.

12 And all the devils besought him, saying, Send us into the swine, that we may enter into them.

13 And forthwith Jesus gave them leave. And the unclean spirits went out, and entered into the swine: and the herd ran violently down a steep place into the sea, (they were about two thousand;) and were choked in the sea.

14 And they that fed the swine fled, and told it in the city, and in the country. And they went out to see what it was that was done.

15 And they come to Jesus, and see him that was possessed with the devil, and had the legion, sit. ting, and clothed, and in his right mind : and they were afraid.

16 And they that saw it told them how it befell to him that was possessed with the devil, and also concerning the swine.

17 And they began to pray him to depart out of their coasts.

18 And when he was come into the ship, he that had been possessed with the devil prayed him that he might be with him.

19 Howbeit Jesus suffered him not, but saith unto him, Go home to thy friends, and tell them how great things the Lord hath done for thee, and hath had compassion on thee.

20 And he departed, and began to publish in Decapolis how great
EV. MARKOŠIAUS; V.

10 Ir prašè jo labai, kad juos ne rarytu iš tos šalies.

11 Ir buvo ten pas kalnus didè kiauliu kaimenė ant ganyklos.

12 Ir prašè jo visi velniai, sakydami: leisk mus $i$ tas kiaules ieiti.

13 Ir tuojaus pavelijo jiems Jèzus. Tai nečystosios dvasẻs išejusios èjo ị kiaules; ir kaimenè padurmai isimeté nuo kranto i mares, (bet ju buvo apie du tukstančiu,) ir nuskendo marèse.

14 Ir kiauliụ kerdžiai pabège, pasakè tai mieste ir kiemuose. Ir jie išèjo žiurèti, kas buvo nusidavę.

15 Ir atėjo pas Jèzu ir pamatẻ tą, kurs buvo velniu vargintas, kad sédẻjo apvilktas, savo protą turèdamas, ir jie bijojos.

16 Ir tie, kurie tai rege̊ję buvo, sakè jiems, kas buvo tikęsi tam velniụ vargintamjam ir kiaulèms

17 Ir pradejjo jo melsti, kad išeitu iš ju rubežių.

$18 \mathrm{Ir}$ kaip jis ižzengė i laivą, prašè ji velnio vargintasis, kad pas ji butu.

19 Bet Jèzus ji ne leido pas savę buti, bet sakè jam: eik i savo namus ir pas savuosius, ir apsakyk jiems, kokią didę geradèjystę tau išrodè Viešpats, ir kaip tavęs susimilo.

20 Ir jis nuẻjęs pradẻjo apsakyti dešimts miestuose, kokią didę 
ST. MARK, V.

things Jesus had done for him: and all mon did marvel.

21 And when Jesus was passed over again by ship unto the other side, much people gathered unto him: and he was nigh unto the sea.

22 And, behold, there cometh one of the rulers of the synagogue, Jairus by name; and when he saw him, he fell at bis feet,

23 And besought him greatly, saying, My little daughter lieth at the point of death : I pray thee, come and lay thy hands on her, that she may be healed; and she shall live.

24 And Jesus went with him; and much people followed him, and thronged him.

25 And a certain woman, which had an issue of blood twelve years,

26 And had suffered many things of many physicians, and had spent all that she had, and was nothing bettered, but rather grew worse,

27 When she had heard of Jesus, came in the press behind, and touched his garment.

28 For she said, If I may touch but his clothes, I shall be whole.

29 And straightway the fountain of her blood was dried up; and she felt in her body that she was healed of that plague.

30 And Jesus, immediately knowing in himself that virtue had gone out of him, turned him about in the press, and said, Who touched my clothes?

'31. And his disciples said unto
EV. MARKOŠIAUS, V.

geradẻjystę jam Jèzus išrodęs; ir visi dyvijosi.

21 Ir kaip Jèzus vèl peréjo su laivu, susirinko pas ji daug žmonių ; o jis buvo prie marių.

22 Ir štai, atèjo viens vyriausias mokyklos, vardu Jairus, ir pamatęs ji, atsiklaupè,

23 Ir didei jo meldé, tarydamas: mano duktè marinama; ateik, prašau, ir uždèk ant jos savo ranką, kad išgytı̣ ir išliktų.

$24 \mathrm{Ir}$ jis nuejo su juomi. Ir sekè ji daug žmonių ir spaudè ji

25 Ir buvo čia moteriškè, kuri kraujo pludimu dvylika metu buvo sirgusi,

26 Ir daug kentejusi nuo daug liekoriu, ir visa savo turta dèl to praradusi, ir nieko jai ne mačijo, bet dar labiaus piktyn èjo su ja.

27 Ta išgirdusi apie Jèzụ, atèjo iš užpakalio tarp žmonių, ir pakrutino jo rubą.

28 Nès ji sakè: kad tiktai jo ruba pakrutinčiau, tai aš išgyčiau.

29 Ir tuojaus apsistojo jos kraujo pludimas, ir ji pasijuto savo kune pasveikusi nuo tos slogos.

30 Ir tuojaus pajuto Jèzus savyje, tą maci iš jo išèjusią, ir atsigręžęs žmonèms tarè: kas pakrutino mano rubus?

31 Ir mokįtiniai sakè jam: matai, 
St. MARK, V.

him, Thou seest the multitude thronging thee, and sayest thou, Who touched me?

32 And he looked round about to see her that had done this thing.

33 But the woman fearing and trembling, knowing what was done in her, came and fell down before him, and told him all the truth.

34 And he said unto her, Daughter, thy faith hath made thee whole; go in peace, and be whole of thy plague.

35 While he yet spake, there came from the ruler of the synagogue's house certain which said, Thy daughter is dead: why troublest thou the Master any further?

36 As soon as Jesus heard the word that was spoken, he saith unto the ruler of the synagogue, Be not afraid, only believe.

37 And he suffered no man to follow him, save Peter, and James, and John the brother of James.

38 And he cometh to the house of the ruler of the synagogue, and seeth the tumult, and them that wept and wailed greatly.

39 And when he was come in, he saith unto them, Why make ye this ado, and weep? the damsel is not dead, but sleepeth.

40 And they laughed him to scorn. But when he had put them all out, he taketh the father and the mother of the damsel, and them that were with him, and entereth in where the damsel was lying.

41 And he took the damsel by the hand, and said unto her, Tali-
EV. MARKOŠIAUS, V.

kad žmonẻs spaudžia tavę, o tu sakai: kas manę pakrutino?

32 Ir jis apsižvalgẻ tos, kuri tai padariusi buvo.

33 Bet ta moteriškẻ bijojosi ir drebèjo, (nės žinojo, kas jai buvo tikęsi,) atèjo ir puolè ties juomi i kelius, ir iškalbèjo visą tiesą.

34 Bet jis tarė jai: mano duktė, tavo tikéjimas tavę pasveikino; eik su pakajumi, ir buk sveika nuo tos tavo slogos!

$35 \mathrm{Jam}$ taip dar bekalbant, atėjo keli iš šeimynos vyriausiojo mokyklos, sakydami: tavo duktẻ numirè; kam toliaus procès darai mokitojui?

36 Bet Jèzus veikiai išgirdo tą kalbą sakytają, ir tarè vyriausiamjam mokyklos: nesibijok, tikt tikèk!

37 Ir ne leido nei vieną, jị sekti, kaip tikt Petrą ir Jokubą bei Joną, Jokubo broli.

$38 \mathrm{Ir}$ jis atėjo i namus vyriausiojo mokyklos, ir matė trenksmą ir labai verkiančius bei raudojančius.

39 Ir ł̇èjęs tarè jiems: kodèl trenksmą darote ir verkiate? tas kudikis ne numiręs, bet miegti; ir jie išjuoke ji.

$40 \mathrm{Ir}$ jis išvaręs visus, èmė su savimi tẻvą ir motyną kudikio ir tus, kurie pas ji buvo, ir iejo kur kudikis gulẻjo.

41 Ir nutvẻręs kudikị prie rankos, tarẻ jai: Talita kumi! tai musy 
ST. MARK, V. VI.

tha cumi; which is, being interpreted, Damsel, I say unto thee, arise.

42 And straightway the damsel arose, and walked; for she was of the age of twelve years. And they were astonished with a great astonishment.

43 And he charged them straitly that no man should know it; and commanded that something should be given her to eat.

\section{CHAPTER VI.}

ND he went out from thence, $A$ and came into his own country; and his disciples follow him.

2 And when the sabbath day was come, he began to teach in the synagogue : and many hearing him were astonished, saying, From whence hath this man these things? and what wisdom is this which is given unto him, that even such mighty works are wrought by his hands?

3 Is not this the carpenter, the son of Mary, the brother of James, and Joses, and of Juda, and Simon? and are not his sisters here with us? And they were offended at him.

4 But Jesus said unto them, A prophet is not without honour, but in his own country, and among his own kin, and in his own house. 5 And he could there do no mighty.. work, save that he laid his hands upon a few sick folk, and healed them.

6 And he marvelled because of their unbelief. And he went round about the villages, teaching.
EV. MARKOŠIAUS, V. VI.

žodžiu: mergait, sakau tau kelkis!

42 Ir tuojaus mergaitė kèlèsi ir vaikščiojo; bet ji buvo dvylika metų sena; ir jie labai stebèjosi.

$43 \mathrm{Ir}$ jis didei jiems isakè, idant tai nieks ne ištirtų; ir sakè, kad duotu jai valgyti.

\section{PERSKYRIMAS VI.}

TR jisai išèjo iš čia ir atejo i savo 1 tẻviškę, ir jo mokịtiniai sekẻ ji.

2 Ir sabatai prièjus, pradėjo jis mokinti ju mokykloje. Ir daug, kurie klausès, stebèjosi jo pamokslo, ir tarè: iš kur jam tai, ir kokia ta išmintis, kuri jam duota yra, ir tokie darbai, kurie per jo rankas daromi!

3 Ar jisai ne cimerninkas, Marijos sunus, ir brolis Jokubo ir Jozès, ir Judo ir Simono? argi ne ir jo sesers šičion yra prie musų? ir jie pasipiktino iš jo.

4 Bet Jèzus tarẻ jiems: prarakas niekur už mažesni ne laikomas, kaip savo tẻviškẻje ir namieji prie savujų.

5 Ir ne galejo tenai padaryti nei jokio stebuklo, kaip tikt keliems ligonims jis uždèdamas rankas juos išgydè.

$6 \mathrm{Ir}$ jis dyvijosi ju netikèjimo. Ir pervaikščiojo miestelius aplinkui mokịdamas. 
St. MARK, VI.

7 And he called unto him the twelve, and began to send them forth by two and two; and gave them power over unclean spirits; 8 And commanded them that they should take nothing for their journey, save a staff only; no scrip, no bread, no money in their purse :

9 But be shod with sandals; and not put on two coats.

10 And he said unto them, In what place soever ye enter into an house, there abide till ye depart from that place.

11 And whosoever shall not receive you, nor hear you, when ye depart thence, shake off the dust under your feet for a testimony against them. Verily I say unto you, It shall be more tolerable for Sodom and Gomorrha in the day of judgment, than for that city.

12 And they went out, and preached that men should repent.

13 And they cast out many devils, and anointed with oil many that were sick, and healed them.

14 And king Herod heard of him; (for his name was spread abroad:) and he said, That John the Baptist was risen from the dead, and therefore mighty works do shew forth themselves in him.

15 Others said, That it is Elias. And others said, That it is a prophet, or as one of the prophets.

16 But when Herod heard there. of, he said, It is John, whom I beheaded : he is risen from the dead.

17 For Herod himself had sent forth and laid hold upon John, and bound him in prison for Herodias' sake, his brother Philip's wife : for he had married her.
EV. MARKOŠIAUS, VI.

$7 \mathrm{Ir}$ suvadinęs anus dvylika, pradejjo juos po du bei du išsiųsti, ir davè jiems maci ant nečysty dvasiu.

8 Ir liepé jiems, kad nieko drauge ne imtus ant kelio, kaip tikt lazdą; nei delmono, nei duonos, nei pinigu čerasle;

9 Bet butu kurpèti; ir ne apsivilktụ dviem sermėgom.

10 Ir sakẻ jiems: $\mathfrak{i}$ kurius namus ieisite, tuose pasilikite, iki iš ten vèl atstosite.

11 Ir kurie jus ne priima, nei jųsu klauso, nuo ty atstokite, ir nukratykite dulkes nuo savo koju, liudymui ant jų. Iš tiesos sakau jums: lengviaus bus Sodomai ir Gomorai sudnoje dienoje, ne kaip tokiam miestui.

12 Ir jie išẻję apsakè, kad prisiverstu.

13 Ir išvarè daug velniu, ir daug ligoniụ aliejumi mostijo, ir išgydė juos.

14 Ir išgirdęs tai karalius Erodas, (nės jo vardas jau žinomas buvo,) tarè: Jonas krikštytojis kẻlèsi iš numirusiu; todèl jis tokius stebuklus daro.

15 Bet keli sakè: jis Eliošius yra; kiti vèl sakè: jis prarakas, arba praraku vienas.

16 Bet Erodas tai išgirdęs taré: jis Jonas, kuriam aš galvą nukirsdinau; tasai kèlès iš numirusių.

17 Bet jis, Erodas, buvo nusiuntęs ir sugaudinęs Joną ir apkaldinęs, dèl Erodyados, pačios Pilipo, savo brolio; nès ją buvo vedęs. 
ST. MARK, VI.

18 For John had said unto Herod, It is not lawful for thee to have thy brother's wife.

19 Therefore Herodias had a quarrel against him, and would have killed him; but she could not :

20 For Herod feared John, knowing that he was a just man and an holy, and observed him; and when he heard him, he did many things, and heard him gladly.

21 And when a convenient day was come, that Herod on his birthday made a supper to his lords, high captains, and chief estates of Galilee;

22 And when the daughter of the said Herodias came in, and danced, and pleased Herod and them that sat with him, the king said unto the damsel, Ask of me whatsoever thou wilt, and I will give it thee. 23 And he sware unto her, Whatsoever thou shalt ask of me, I will give it thee, unto the half of my kingdom.

24 And she went forth, and said unto her mother, What shall I ask? And she said, The head of John the Baptist.

25 And she came in straightway with haste unto the king, and asked, saying, I will that thou give me by and by in a charger the head of John the Baptist.

26 And the king was exceeding sorry; yet for his oath's sake, and for their sakes which sat with him, he would not reject her.

27 And immediately the king sent an executioner, and commanded his head to be brought: and he went and beheaded him in the prison,

28 And brought his head in a
EV. MARKOŠIAUS, VI.

18 Bet Jonas sakè Erodui: ne vale tau, savo brolio pačią turẻti.

19 Ale Erodyada tykojo jo, ir norejjo ji nužavinti, bet ne galèjo.

20 Bet Erodas bijojosi Jono; nès jis žinojo, ji vyrą teisu ir šventą esanti; ir dabojo ant jo, klausydavo jo daug daiktuose, ir mielai jo klausès.

$21 \mathrm{Ir}$ atèjo diena patogi, kad Erodas, švęsdamas savo nžgimimo dieną, pataisè vakarienę pulkauninkams, šimtininkams ir vyresniemsiems Galilèos.

22 Tai i̇ejo duktè Erodyados ir šokinėjo ir pamègo Erodui ir drauge už stalo sẻdintiemsiems. Tai sakè karalius mergaitei: prašyk iš manęs, ko tu nori, aš tau duosu.

23 Ir prisiekè jai: ką iš manęs prašysi, duosu tau, iki pusès savo karalystès.

24 Ir išèjusi tarè savo motynai: ko prašysu? ta atsakè: galvos Jono krikšty tojo.

25 Ir ji pasiskubịdama i̇ejusi veikiai pas karalių, prašé jo, sakydama: noru, kad man dabar tuojaus duotumbei ant bliudo galva Jono krikštytojo.

26 Karalius smutnijosi; ale dèl prysiegos ir dèl drauge už stalo sèdinčiuju ne norèjo jos prašyma paniekinti.

27 Ir tuojaus nusiuntęs karalius budeli, liepè atgabenti jo galvą. Tas nuejjęs nukirto jam tą kalèjime.

28 Ir atnešè jo galvą bliude, ir 
charger, and gave it to the damsel : and the damsel gave it to her mother.

29 And when his disciples heard of it, they came and took up his corpse, and laid it in a tomb.

30 And the apostles gathered themselves together unto Jesus, and told him all things, both what they had done, and what they had taught.

31 And he said unto them, Come ye yourselves apart into a desert place, and rest a while: for there were many coming and going, and they had no leisure so much as to eat.

32 And they departed into a desert place by ship privately.

33 And the people saw them departing, and many knew him, and ran afoot thither out of all cities, and outwent them, and came together unto him.

34 And Jesus, when he came out, saw much people, and was moved with compassion toward them, because they were as sheep not having a shepherd: and he began to teach them many things.

35 And when the day was now far spent, his disciples came unto him, and said, This is a desert place, and now the time is far passed :

36 Send them away, that they may go into the country round abcut, and into the villages, and buy themselves bread: for they have nothing to eat.

$37 \mathrm{He}$ answered and said unto them, Give ye them to eat. And they say unto him, Shall we go and buy two hundred pennyworth of bread, and give them to eat? davẻ tą mergaitei, ir mergaitė davè tą savo motynai.

29 Ir tai išgirdę jo mokįtiniai atẻjo, ir èmè jo lavoną, ir padejjo ji i kapą.

30 Ir apaštalai susièje pas Jèzu, pasakè jam tai vislab, ir ką jie buvo darę ir mokinę.

31 Ir jis sakè jiems: eikime vieni skyriu î pusčią, ir maž atsiilsèkite; nès tú daug buvo, kurie ateidavo ir šalin eidavo; ir ne gana atspèjo nei valgyti.

32 Ir jis perejo laivu $\mathfrak{i}$ pusčią skyriu.

33 Ir žmonès matė juos atstojančius; ir daug ji pažino, ir susibėgo ten pèsti iš visu miestų, ir pralenkè juos, ir atèjo pas ji.

34 Ir Jèzus išèjęs pamatè daugumą žmonių ir pasigailèjo jụ, kad jie buvo kaip avys, neturinčios kerdžiaus. Ir pradejo ilgai Dievo žodi sakyti.

35 Ir dienai jau veikiai besibaigiant, priējo ji jo mokịtiniai, sakydami: pusčia čionai ir diena jau praejo.

36 Leisk juos nuo savęs, kad nuèje aplinkui i kiemus ir miestelius, pirktųs sau duonos; nès ne tur ko valgyti.

37 Bet Jèzus atsakydamas tarè jiems: duokite jus jiems valgyti. Ir jie sakè jam: ar nuẻje pirksime duonos už du šimtu grašių, ir duosime jiems valgyti? 
ST. MARK, VI.

$38 \mathrm{He}$ saith unto them, How many loaves have ye? go and see. And when they knew, they say, Five, and two fishes.

39 And he commanded them to make all sit down by companies upon the green grass.

40 And they sat down in ranks, by hundreds, and by fifties.

41 And when he had taken the five loaves and the two fishes, he looked up to heaven, and blessed, and brake the loaves, and gave them to his disciples to set before them; and the two fishes divided he among them all.

42 And they did all eat, and were filled.

43 And they took up twelve baskets full of the fragments, and of the fishes.

44 And they that did eat of the loaves were about five thousand men.

45 And straightway he constrained his disciples to get into the ship, and to go to the other side before unto Bethsaida, while he sent away the people.

46 And when he had sent them away, he departed into a mountain to pray.

47 And when even was come, the ship was in the midst of the sea, and he alone on the land.

48 And he saw them toiling in rowing; for the wind was contrary unto them : and about the fourth watch of the night he cometh unto them, walking upon the sea, and would have passed by them.

49 But when they saw him walking upon the sea, they supposed it had been a spirit, and cried out:
EV. MARKOŠIAUS, VI.

38 Bet jis sakè jiems: kiekgi kepalų turite? eikite ir žiurèkite! Ir jie peržiurẻję pasakè: penkis, ir dvi žuvi.

39 Ir jis liepẻ jiems, kad visi eilėmis, kaip apie stalus, pasisėstu ant žalios žolès.

40 Ir jie sèdosi eilèmis; šimtais ir šimtais, penkisdešimtais ir penkisdešimtais.

$41 \mathrm{Ir}$ èmęs tus penkis kepalus duonos ir tiedvi žuvi, pažiurèjo dangun, ir dèkavojęs laužè duoną, ir davé savo mokitiniams, kad jiems padẻtų, ir tiedvi žuvi visiems išdalijo.

\section{Ir visi valgẻ ir privalgè.}

$43 \mathrm{Ir}$ surinko trupučiu, dvylika pintinių pilnų, ir nuo žuvių.

$44 \mathrm{Ir}$ valgiusiųjų buvo penki tukstančiai vyrų.

$45 \mathrm{Ir}$ tuojaus jis privertè savo mokitinius, kad jie ièje i laivą, pirm jo pereitu i Betsaida, iki jis paleisiąs žmones nuo savęs.

46 Ir jis paleidęs juos nuo savęs, užèjo ant kalno melstisi.

$47 \mathrm{Ir}$ ant vakaro buvo laivas viduryje mariu, o jis viens ant krašto.

$48 \mathrm{Ir}$ jis regejo, kad jie vargo irdamiesi; nès vẻjas jiems buvo i akis. Ir apie ketvirtają nakties sargybę atejjo jis pas juos, vaikščiodamas ant mariu;

49 Ir norèjo pro juos praeiti. Ir ji pamate vaikščiojanti ant mariu, mislijo, deivę esant, ir šaukè. 
St. MAlR, VI. VII.

50 For they all saw him, and were troubled. And immediately he talked with them, and saith unto them, Be of good cheer : it is I; be not afraid.

51 And he went up unto them into the ship; and the wind ceased; and they were sore amazed in themselves beyond measure, and wondered.

52 For they considered not the miracle of the loaves: for their heart was hardened.

53 And when they had passed over, they came into the land of Gennesaret, and drew to the shore.

54 And when they were come out of the ship, straightway they knew him,

55 And ran through that whole region round about, and began to carry about in beds those that were sick, where they heard he was.

56 And whithersoever he entered, into villages, or cities, or country, they laid the sick in the streets, and besought him that they might touch if it were but the border of his garment: and as many as touched him were made whole.

\section{CHAPTER VII.}

THEN came together unto him the Pharisees, and certain of the scribes, which came from Jeru. salem.

2 And when they saw some of his disciples eat bread with defiled, that is to say, with unwashen, hands, they found fault.

3 For the Pharisees, and all the Jews, except they wash their hands oft, eat not, holding the tradition of the elders.
EV. MARKOŠIAUS, VI. VII.

50 Nès visi ji regẻjo ir nusigando. Bet jis tuojaus kalbejo su jais, ir tarẻ jiems: bukite linksmi! aš esmi, nesibijokite!

51 Ir jžzengė pas juos i laivą, ir vejjas nustojo. Ir jie stebéjosi ir dyvijosi labai didei.

52 Nès jie ne buvo išmintingesni pastoję iš to stebuklo, su duona darytojo, ir ju širdis buvo užkietusi.

53 Ir persiyrę atėjo i žemę Genèzaret ir prisiyrè prie krašto.

54 Ir kaip jie iškopo iš laivo, tuojaus ji pažindami,

55 Nubėge i visas aplink esančias šalis, pradejjo ligonis pas ji gabenti ant patalụ, kur tikt ištyrè, ji esanti.

$56 \mathrm{Ir}$ kur jis jèjo i miestelius, arba i miestus, arba i kiemus, čia paguldé ant turgaus ligonis, ir meldè jo, kad jie tikt sermègos siulę pakrutịti gautų; ir visi, kurie ji pakrutino, išgijo.

\section{PERSKYRIMAS VII.}

TR susirinko pas ji Parizèušiai ir keli raštemokịtujju, kurie iš Jèruzalès atėję buvo.

2 Ir jie išvydę kelis jo mokitinių nečystomis, (tai esti, nemazgotomis) rankomis duona valgant, išpeikè tai.

3 Nès Parizèušiai ir visi Žydai ne valgo, nesimazgoje tankiai savo rankas; taipo jie laiko istatymus savo vyresniųjų. 
St. MARK, VII.

4 And when they come from the market, except they wash, they eat not. And many other things there be, which they have received to hold, as the washing of cups, and pots, brasen vessels, and of tables.

5 Then the Pharisees and scribes asked him, Why walk not thy disciples according to the tradition of the elders, but eat bread with unwashen hands?

$6 \mathrm{He}$ answered and said unto them, Well hath Esaias prophesied of you hypocrites, as it is written, This people honoureth me with their lips, but their heart is far from me.

7 Howbeit in vain do they worship me, teaching for doctrines the commandments of men.

8 For laying aside the commandment of God, ye hold the tradition of men, as the washing of pots and cups : and many other such like things ye do.

9 And he said unto them, Full well ye reject the commandment of God, that ye may keep your own tradition.

10 For Moses said, Honour thy father and thy mother; and, Whoso curseth father or mother, let him die the death :

11 But ye say, If a man shall say to his father or mother, It is Corban, that is to say, a gift, by whatsoever thou mightest be profited by me; he shall be free.

12 And ye suffer him no more to do ought for his father or his mother;

13 Making the word of God of none effect through your tradition,
EV. MARKOŠIAUS, VII.

$4 \mathrm{Ir}$ iš turgaus parẻje jie ne valgo nesimazgoję. Ir tokių daiktu daug yra, kurius jie yra priẻme laikyti, kaipo mazgojima kupku ir kragu, ir varinių rykų ir stalų.

5 Dèlgi to klausẻ ji Parizèušiai ir raštemokitieji: kodèl tavo mokitiniai ne elgiasi pagal istatymus vyresniuju, bet duona valgo nemazgotomis rankomis?

6 Bet jis atsakydamas tarè jiems: labai gerai Jẻzaiošius yra apie jus veidmainius prarakavęs, kaipo parašyta: Šie žmonès garbina manę lupomis, bet ju širdis toli yra nuo manęs.

7 Bet noprosnai yra, kad jie man šlužija, kadangi mokina toki mokslą, kursai tikt žmonių issakymas yra.

8 Jus prastojate Dievo prisakymus ir laikote žmoniu istatymus, mazgojimą kragu ir kupkų; ir daug tiems lygiu daiktu darote.

9 Ir sake jiems: bais gerai paniekinote Dievo prisakymus, kad savo istatymus laikytumbite.

10 Nès Maižěšius sakè: garbink savo tẻvą ir savo motyną; ir kas tẻvui ir motynai keikia, tas tur smerčiu mirti.

11 Bet jus mokinate, kad kas tévui arba motynai sako: korban, tai esti: kad aš tai apieravoju, tai tau toktai toli naudingiaus yra, tas gerai daro.

12 Ir tokiu budu ne leidžiate ji, toliaus ko gero daryti savo tẻvui arba savo motynai,

13 Ir nieku verčiate Dievo žodi savo istatymais, kurius prasima- 
Sr. MARK, VII.

which ye have delivered: and many such like things do ye.

14 if And when he had called all the people unto him, he said unto them, Hearken unto me every one of you, and understand :

15 There is nothing from without a man, that entering into him can defile him : but the things which come out of him, those are they that defile the man.

16 If any man have ears to hear, let him hear.

17 And when he was entered into the house from the people, his disciples asked him concerning the parable.

18 And he saith unto them, Are ye so without understanding also? Do ye not perceive, that whatso. ever thing from without entereth into the man, it cannot defile him;

19 Because it entereth not into his heart, but into the belly, and goeth out into the draught, purging all meats?

20 And he said, That which cometh out of the man, that defileth the man.

21 For from within, out of the heart of men, proceed evil thoughts, adulteries, fornications, snurders,

22 Thefts, covetousness, wickedness, deceit, lasciviousness, an evil eye, blasphemy, pride, foolishness :

23 All these evil things come from within, and defile the man.

24 I And from thence he arose, and went into the borders of Tyre and Sidon, and entered into an house, and would have no man know it: but he could not be hid. 25 For a certain woman, whose
EV. MARKOŠIAUS, VII.

nète; ir daug tiems lygiu daikty darote.

14 Ir prisivadinęs pas savę visus žmones, tarẻ jiems: klausykite manęs visi, ir išmanykite!

15 Nei joks daiktas, iš viršaus ieinąsis $\mathfrak{i}$ žmogụ, negal ji nečystą daryti, bet išeinąsis iš jo, ji nečystą daro.

16 Jei kas tur ausių klausyti, tas te klauso.

17 Ir kaip jis nuo žmoniu atējo i namus, klausė ji jo mokitiniai apie ta prilyginimą.

$18 \mathrm{Ir}$ jis sakè jiems: argi ir jus tokie ne išmana esate? ar dar ne išmanote, kad vislab, kas iš viršaus ieina $\mathfrak{i}$ žmogu, ne gal ji nečysta daryti?

19 Nès ne ieiti $i$ jo širdi, bet $i$ pilva, ir išeiti per išeiga priliktaja, kuri iščystija visus įvalgymus.

20 Ir jis sakè: kas išeina iš žmogaus, tai zmogu nečystą daro.

21 Nès iš vidaus, iš širdies žmogaus, išeiti piktos dumos, venčiavonystės peržengimas, kekšystė, razbajystè,

22 Vagystė, godas, piktenybė, vylius, neviežlybystè, nelaba akis, Dievo bluznijimas, didystè, n'išmintis.

23 Visi tie piktieji daiktai išeiti iš vidaus, ir žmogy nečysta daro. 24 Ir kèlęsi paèjo jis iš čia i rubežius Tyraus ir Sidono, ir i̇ejęs i namus, ne norejjo, kad tai kas žinotu, o tikt ne galèjo pasislëpti.

25 Nès moteriškè, kurios duktelẻ 
ST. MARK, VII.

young daughter had an unclean spirit, heard of him, and came and fell at his feet:

26 The woman was a Greek, a Syrophenician by nation; and she besought him that he would cast forth the devil out of her daughter.

27 But Jesus said unto her, Let the children first be filled : for it is not meet to take the children's bread, and to cast it unto the dogs.

28 And she answered and said unto him, Yes, Lord : yet the dogs under the table eat of the children's crumbs.

29 And he said unto her, For this saying go thy way; the devil is gone out of thy daughter.

30 And when she was come to her house, she found the devil gone out, and her daughter laid upon the bed.

31 I And again, departing from the coasts of Tyre and Sidon, he came unto the sea of Galilee, through the midst of the coasts of Decapolis.

32 And they bring unto him one that was deaf, and had an impediment in his speech; and they beseech him to put his hand upon him.

33 And he took him aside from the multitude, and put his fingers into his ears, and he spit, and touched his tongue;

34 And looking up to heaven, he sighed, and saith unto him, Ephphatha, that is, $\mathrm{Be}$ opened.

35 And straightway his ears were opened, and the string of his tongue was loosed, and he spake plain.

36 And he charged them that
EV. MARKOŠIAUS, VII.

nečystą dvasę turẻjo, girdẻjusi apie ji, atẻjo ir atsiklaupè pas jo kojas.

26 (Ir ji buvo Grykiška moteriškẻ iš Syropẻnycios) ir meldẻ jo, kad velnią išvarytų iš jos dukters.

27 Bet Jèzus sakẻ jai: tesisotina pirmiaus vaikai. Negražus daiktas yra, vaiku duoną imti, ir šunims pamesti.

28 Bet ji atsakydama tarè jam: berods Viešpatie, ale tikt ir šunyčiai èda po stalu nuo vaikut trupučiul.

29 Ir jis sakẻ jai: to žodžio dẻlei eik; velnias iš tavo dukters išèjo.

30 Ir ji parejusi i savo namus, rado velnią išèjusi, ir dukteri be gulinčią patale.

31 Ir jis vẻl išẻjęs iš rubežiu Tyraus ir Sidono, atejo pas mares Galilèos, viduryje rubežiu dešimties miestu.

32 Ir atvedè pas ji kurtini, nebyli esanti, ir meldé jo, kad ranka ant jo uždètu.

$33 \mathrm{Ir}$ jis èmęs ji nuo žmoniu skyriu, idejojo pirštus i jo ausis, ir spiovęs pakrutino jo liežuvi,

34 Ir pažiurẻjęs dangun atsidusejo, ir tarẻ jam: Epata! tai musu žodžiu: atsiverk!

35 Ir tuojaus atsivèrè jo ausys, ir ryšys jo liežuvio išsirišo, ir gerai iškalbèjo.

36 Ir jis uždraudė jiems, idant 
ST. MARK, VII. VIII.

they should tell no man : but the more he charged them, so much the more a great deal they published it;

37 And were beyond measure astonished, saying, $\mathrm{He}$ hath done all things well: he maketh both the deaf to hear, and the dumb to speak.

\section{CHAPTER VIII.}

$\mathrm{T} \mathrm{N}$ those days the multitude be1 ing very great, and having nothing to eat, Jesus called his disciples unto him, and saith unto them,

2 I have compassion on the multitude, because they have now been with me three days, and have nothing to eat:

3 And if I send them away fasting to their own houses, they will faint by the way: for divers of them came from far.

4 And his disciples answered him, From whence can a man satisfy these men with bread here in the wilderness?

5 And he asked them, How many loaves have ye? And they said, Seven.

6 And he commanded the people to sit down on the ground : and he took the seven loaves, and gave thanks, and brake, and gave to his disciples to set before them; and they did set them before the people.

7 And they had a few small fishes: and he blessed, and commanded to set them also before them.

8 So they did eat, and were
EV. MARKOŠIAUS, VII. VIII. tai niekam ne sakytu. Ale juo labiaus jis uždraudè, juo daugiaus jie tai išplatino.

37 Ir labai didei dyvijosi, sakydami: jis vislab gerai padarè, kurtinius jis daro girdinčius, ir nebylius kalbančius.

\section{PERSKYRIMAS VIII.}

TUUOČĚS, kaip daug žmonių čia 1 buvo, ir ne turẻjo ko valgyti, pasivadinęs Jèzus savo mokịtinius, tarè jiems:

2 Gailiuos žmonių; nẻs jau tris dienas pas manę išburo, ir ne tur ko valgyti;

3 Ir kad juos nuo savęs išalkusius namon parleisčiau, ant kelio apalptų; nès keli iš tolo buvo atèję.

4 Ir jo mokitiniai atsakè jam: kur imsime duonos čionai pusčioje, juos pasotinti?

5 Ir jis ju klausẽ: kiek duonos kepalu turite? jie atsakè: septynis.

$6 \mathrm{Ir}$ jis liepè žmonèms sèstis ant žemès. Ir èmęs tus septynis kepalus, dẻkavojęs laužè tus ir davè savo mokitiniams, kad jiems padètų. Ir jie padẻjo žmonėms.

7 Ir turejo mažai žuvelių; ir dèkavojęs liepè tas padalyti.

8 Bet jie valgè ir privalgè, ir 
St. MARK, VIII.

filled: and they took up of the broken meat that was left seven baskets.

9 And they that had eaten were about four thousand: and he sent them away.

10 I And straightway he entered into a ship with his disciples, and came into the parts of Dalmanutha.

11 And the Pharisees came forth, and began to question with him, seeking of him a sign from heaven, tempting him.

12 And he sighed deeply in his spirit, and saith, Why doth this generation seek after a sign? verily I say unto you, There shall no sign be given unto this genera. tion.

13 And he left them, and entering into the ship again departed to the other side.

14 II Now the disciples had forgotten to take bread, neither had they in the ship with them more than one loaf.

15 And he charged them, saying, Take heed, beware of the leaven of the Pharisees, and of the leaven of Herod.

16 And they reasoned among themselves, saying, It is because we have no bread.

17 And when Jesus knew it, he saith unto them, Why reason ye, because ye have no bread? perceive ye not yet, neither understand? have ye your heart yet hardened?

18 Having eyes, see ye not? and having ears, hear ye not? and do ye not remember?

19 When I brake the five loaves ansong five thousand, how many
EV. MARKOŠIAUS, VIII.

surinko likusiuju trupučiu septynis pintinius.

9 Ir valgiusiuju buvo kokie keturi tukstančiai. Ir jis paleido juos nuo savęs.

10 Ir tuojaus ižzengęs i laivą su savo mokịtiniais atėjo $i$ šali Dalmanutą.

11 Ir Parizẻušiai išèję pradẻjo su juomi klausinètisi, gundè ji, ir prašè iš jo ženklo iš dangaus.

$12 \mathrm{Ir}$ jis atsidusėjo savo dvasẻje, ir tarè: kogi jèško ši giminẻ ženklo? iš tiesos, aš sakau jums: šiai giminiai ne bus duotas nei joks ženklas.

13 Ir palikęs juos, vèl jižengè $\mathfrak{i}$ laivą ir perẻjo $\mathfrak{i}$ antrąja pusę.

14 Ir jie buvo užmiršę duonos drauge imtis, ir ne turèjo daugiaus pas savę laive, kaip tikt viena kepalą duonos.

$15 \mathrm{Ir}$ jis liepè jiems, tarydamas: dabokitès ir saugokitès raugo $\mathrm{Pa}$ rizėušị ir raugo Erodo.

16 Ir jie šeip ir taip mislydami, tarè kits kitam: apie tai jis kalba, kad mes duonos ne turime.

17 Ir Jèzus, tai numanęs, sakè jiems: kogi rupinatẻs, duonos ne turédami ? ar dar nieko ne permanote ir dar ne suprantate? ar dar turite užkietèjusią širdi savyje?

18 Turèdami akių ne regite, turèdami ausiu ne girdite, ir to ne atsimenate?

19 Kaip penkis kepalus laužian penkiems tukstančiams, kiek čia 
ST. MARK, VIII.

baskets full of fragments took ye up? They say unto him, Twelve. 20 And when the seven among four thousand, how many baskets full of fragments took ye up? And they said. Seven.

21 And he said unto them, How is it that ye do not understand?

22 I And he cometh to Bethsaida; and they bring a blind man unto him, and besought him to touch him.

23 And he took the blind man by the hand, and led him out of the town; and when he had spit on his eyes, and put his hands upon him, he asked him if he saw ought.

24 And he looked up, and said, I see men as trees, walking.

25 After that he put his hands again upon his eyes, and made him look up : and he was restored, and saw every man clearly.

26 And he sent him away to his house, saying, Neither go into the town, nor tell it to any in the town.

27 I And Jesus went out, and his disciples, into the towns of Cæsarea Philippi : and by the way he asked his disciples, saying unto them, Whom do men say that I am?

28 And they answered, John the Baptist : but some say, Elias; and others, One of the prophets.

29 And he saith unto them, But whom say ye that I am? And Peter answereth and saith unto him, Thou art the Christ.

30 And he charged them that they should tell no man of him.

31 And he began to teach them,
EV. MARKOŠIAUS, VIII.

pintiniu pripildète trupučiais? jie sakè : dvylika.

20 Bet kaip septynis kepalus laužiau keturiems tukstančiams, kiek čia pintinių pripildète trupučiais? Jie sakè : septynis.

$21 \mathrm{Ir}$ jis sake jiems: kaipogi nieko ne išmanote?

22 Ir jam atejjus i Betsaidą, atvedè pas ji aklą, melsdami jo, kad jis ji pakrutintu.

23 Ir nutvèręs aklojo ranką, išvedè ji laukan iš miestelio, ir spiovęs i jo akis, uždẻjo savo rankas ant jo, ir klausẻ jo, bau ką regis?

24 Ir jis pažvilgėjo, ir tarẻ: aš matau žmones vaikščiojančius, lyg medžius matąs.

25 Potam jis vèl uždèjo rankas ant jo akiu, ir vèl liepẻ jam žiurèti, ir jis pastojo regįs, kad vislab galejo tikrai matyti.

26 Ir jis parsiunte ji namon, tarydamas: ne eik i miesteli, ir tai nei vienam tame'ne pasakyk.

27 Ir Jẻzus išẻjo su savo mokitiniais $\mathfrak{i}$ miestelius miesto Césarios Pilipi. Ir keliaudamas klausė savo mokitinių, tarydamas jiems: kągi sako žmonẻs manę esanti ?

28 Jie atsakè: sako, tave esanti Joną krikštytoji; kiti sako Eliošių, kiti praraku vieną esantị.

29 Ir jis tarẻ jiems: bet jus ką sakote manę esanti? tai Petras atsakydamas tarè jam: tu esi Kristus.

30 Ir jis uždraudè jiems, kad tai niekam ne sakytul.

31 Ir pradéjo juos mokịti: žmo- 
St. MARK, VIII. IX.

that the Son of man must suffer many things, and be rejected of the elders, and of the chief priests, and scribes, and be killed, and after three days rise again.

32 And he spake that saying openly. And Peter took him, and began to rebuke him.

33 But when he had turned about and looked on his disciples, he rebuked Peter, saying, Get thee behind me, Satan: for thou savourest not the things that be of God, but the things that be of men.

34 I And when he had ealled his people unto him with his disciples also, he said unto them, Whosoever will come after me, let him deny himself, and take up his cross, and follow me.

35 For whosoever will save his life shall lose it; but whosoever shall lose his life for my sake and the gospel's, the same shall save it. 36 For what shall it profit a man, if he shall gain the whole world, and lose his own soul?

$37 \mathrm{Or}$ what shall a man give in exchange for his soul?

38 Whosoever therefore shall be ashamed of me and of my words in this adulterous and sinful generation; of him also shall the Son of man be ashamed, when he cometh in the glory of his Father with the holy angels.

\section{CHAPTER IX.}

$A$ ND he said unto them, Verily A I say unto you, That there be some of them that stand here, which shall not taste of death, till they have seen the kingdom of God come with power.

2 I And after six days Jesus
EV. MARKOŠIAUS, VIII. IX.

gans sunus tur dang kentèti, ir atmestas buti vyresniųju ịr vyriansiųju kunigu ir raštemokitųju, ir užmuštas buti, ir po triju dieny keltis.

$32 \mathrm{Ir}$ jis tą žodi drąsiai ir atvirai. kalbėjo. Ir Petras ji ėmęs $\mathfrak{i}$ šali, pradèjo ji drausti.

33 Bet jis atsigręžęs pažiurèjo i savo mokịtinius, ir sudraudè Petrą, tarydamas: atstok nuo manęs, tu šètone; nès tu ne misliji tai, kas dieviška, bet kas žmogiška yra.

34 Ir prisivadinęs pas savę žmones su savo mokịtiniais, tarẻ jiems: kas manę nor sekti, te užsiginie savęs, ir èmęs savo kryžiu ant savęs, te sekie manę.

35 Nès kas savo gyvasti nor išlaikyti, prapuldys tą; ir kas savo gyvasti prapuldo dèl manęs ir evangèlios dẻlei, tą išlaikys.

36 Ka mačytų žmogui, norint jis visą svieta nusipeluytu, ir iškadą gauty aut savo dušios?

37 Árba ką gal žmogus duoti, kad sava dušią atvaduotu?

38 Bet kursai manęs ir mano žodžių gèdisi tarp šios venčiavonystę peržengiančios ir griekingos giminès, to ir žmogaus sunus gèdėsis, ateidamas šlovèje savo Tẻvo su šventaisiais angielais.

\section{PERSKYRIMAS IX.}

TR jis sake jiems: iš tiesos sakan 1 jums: čia stov keli, tie ne ragaus smerti, iki matys karalystę Dievo ateinančią su mace.

2 Ir po šešių dienų ẻmęs Jèzus 
taketh with him Peter, and James, and John, and leadeth them up into an high mountain apart by themselves: and he was transfigured before them.

- 3 And his raiment became shining, exceeding white as snow; so as no fuller on earth can white them.

4 And there appeared unto them Elias with Moses : and they were talking with Jesus.

5 And Peter answered and said to Jesus, Master, it is good for us to be here : and let us make three tabernacles; one for thee, and one for Moses, and one for Elias.

6 For he wist not what to say; for they were sore afraid.

7 And there was a cloud that overshadowed them: and a voice came out of the cloud, saying, This is my beloved Son : hear him.

8 And suddenly, when they had looked round about, they saw no man any more, save Jesus only with themselves.

9 And as they came down from the mountain, he charged them that they should tell no man what things they had seen, till the Son of man were risen from the dead.

10 And they kept that saying with themselves, questioning one with another what the rising from the dead should mean.

11 I And they asked him, say. ing, Why say the scribes that Elias must first come?

12 And he answered and told them, Elias verily cometh first, and restoreth all things; and how it is written of the Son of man, that he must suffer many things, and be set at nought. pas save Petrą, Jokuba ir Joną, ir užsivedęs juos ant aukšto kalno skyriu vienus, persišvietė po ju akiu.

3 Ir jo rubai pastojo skaistus ir labai balti, kaip sniegas, aža tụ ir nei vienas baltitojis ant žemès ne gal taipo išbaltinti.

4 Ir pasirodè jiems Eliošius su Maižěšiumi, ir susikalbèjo su Jèzumi.

5 Ir atsakydamas Petras tarè Jèzui: Mokitojau, ger čionai buti; pakurkim tris šètras, tau vieną, Maižěšiui vieną, ir Eliošiui vieną.

6 Bet jis ne žinojo, ka kalbąs; nèsa jie buvo persigandę.

7 Ir atèjo debesis: tos šešèlis užèjo ant jų. Ir iš debesies balsas atèjo ir tarè: tas yra mano mielasis sunus, to klausykite.

8 Ir tuojaus po to jie apsižvalge̊ aplinkui, ir ne matè nei vieno daugiaus, kaip tiktai vieną Jèzy pas savę.

9 Bet jiems nueinant nuo kalno, uždraudè jiems Jèzus, kad, ką regèję, niekam ne sakytų, iki žmogaus Sunui iš numirusiųju prisikèlus.

10 Ir jie palaikè tą žodi pas savė, kits kito klausinèdami tarp savęs: kasgi tai yra iš numirusiųju prisikeltis.

11 Ir jie klausè jo, tarydami: juk raštemokịtieji sako, Eliošiu turinti pirma ateiti.

12 Bet jis atsakydamas tarè jiems: Eliošius tur tiesa pirma ateiti ir vislab vèl sutaisyti. Priegtam žmogaus Sunus tur daug kentèti ir paniekintas buti, kaip ir parašyta yra. 
13 But I say unto you, That Elias is indeed come, and they have done unto him whatsoever they listed, as it is written of him. 14 if And when he came to his disciples, he saw a great multitude about them, and the scribes questioning with them.

15 And straightway all the people, when they beheld him, were greatly amazed, and running to him saluted him.

16 And he asked the scribes, What question ye with them?

17 And one of the multitude answered and said, Master, I have brought unto thee my son, which hath a dumb spirit;

18 And wheresoever he taketh him, he teareth him: and he foameth, and gnasheth with his teeth, and pineth away: and I spake to thy disciples that they should cast him out; and they could not.

$19 \mathrm{He}$ answereth him, and saith, 0 faithless generation, how long shall I be with you? how long shall I suffer you? bring him unto me.

20 And they brought him unto him: and when he saw him, straightway the spirit tare him; and he fell on the ground, and wallowed foaming.

21 And he asked his father, How long is it ago since this came unto him? And he said, Of a child.

22 And ofttimes it hath cast him into the fire, and into the waters, to destroy him : but if thou canst do any thing, have compassion on us, and help us.

23 Jesus said unto him, If thou
13 Bet aš sakau jums: Eliošius atėjo, ir jie darè jam, ką norẽjo, kaip apie ji parašyta yra.

$14 \mathrm{Ir}$ atẻjęs pas savo mokitinius, išvydo didę daugybę žmonių aplink juos, ir raštemokitu, su jais pasiklausinẻjančių.

$15 \mathrm{Ir}$ tuojaus visi žmonès, ji išvydę, nusistebèjo ir pribègę pasveikino $\mathrm{ji}$.

16 Ir jis klausẻ raštemokituju: apie ka pasiklausinėjate su jais?

17 Bet viens iš žmoniu atsakydamas tarè: mokịtojau, aš savo sunų atsivedžiau pas tavę, tas tur nekalbančią dvasę.

18 Ir kur ji ji tik sugrieb, čia ji plèšia, ir jis putoja ir griežia dantimis ir džiusta. Aš kalbẻjau su tavo mokitiniais, kad jie ja išvarytų, o jie ne gal.

19 Bet jis atsakydams tarè jam: ak tu netikintiji giminė! kaip ilgai pas jus busu, ir kaip ilgai jus pakęsu? atveskite ji šen pas manę.

$20 \mathrm{Ir}$ jie atvedè ji pas ji. Ir tuojaus, kaip dvasė ji išvydo, plěšè $\mathrm{ji}$, ir jis parpuolè ant žemès ir vartèsi putodamas.

21 Ir jis klausė jo tèvo: kaip seniai tai yra, kad jam tai tikosi? jis atsakè: dar kudikèliui esant.

22 Ir tankiai ji metẽ $i$ ugni ir i vandeni, kad ji nužavintu. Bet jei ka gali, pasigailédamas musų, gelbèk mus.

23 Bet Jèzus tarẻ jam: kad tu 
eanst believe, all things are possible to him that believeth.

24 And straightway the father of the child cried out, and said with tears, Lord, I believe; help thou mine unbelief.

25 When Jesus saw that the people came running together, he rebuked the foul spirit, saying unto him, Thou dumb and deaf spirit, I cliarge thee, come out of him, and enter no more into him.

26 And the spirit cried, and rent him sore, and came out of him : and he was as one dead; insomuch that many said, $\mathrm{He}$ is dead.

27 But Jesus took him by the hand, and lifted him up; and he arose.

28 And when he was come into the house, his disciples asked him privately, Why could not we cast him out?

29 And he said unto them, This kind can come forth by nothing, but by prayer and fasting.

30 I And they departed thence, and passed through Galilee; and he would not that any man should know it.

31 For he taught his disciples, and said unto them, The Son of man is delivered into the hands of men, and they shall kill him; and after that he is killed, he shail rise the third day.

32 But they understood not that saying, and were afraid to ask him.

33 \% And he came to Caper. naum : and being in the house he asked them, What was it that yo disputed among yourselves by the way?

34 But they held their peace: galètumbei tikèti. Visi daiktai tikinčiam yra galimi.

24 Ir tuojaus šaukdamas vaiko tẻvas su ašaromis tarè: tikiu, miels Viešpatie, gelbèk mano netikẻjimą.

25 Ogi regèdamas Jèzus žmones susibẻgant, apdraudẻ nečystają dvase, tarydamas: tu nekalbantiji ir negirdintiji dvasè, aš tau prisa$\mathrm{kau}$, kad iš jo išeitumbei, ir daugiaus $\mathrm{i}$ ji ne ieitumbei.

26 Tai ji šaukè ir didei ji plèšusi, išèjo. Ir jis lyg numiręs buvo, taip, kad daug ir sakè: jis numiręs.

27 Bet Jèzus nutvẻręs jo ranką, attiesè ji, ir jis kèlèsi.

28 Ir jam namon pare̊jus, klausé ji jo mokitiniai skyriu: kodẻl mes ją ne galéjome išvaryti?

29 Ir jis atsakẻ: ši veislè niekaip ne gal išeiti, kaip tikt per maldas ir pastnikavimus.

30 Ir jie iš čia šalin atstoję, keliavo per Galileaą, ir jis ne norèjo, kad tai kas žinotų.

31 Bet jis mokino savo moki. tinius ir tarẻ jiems: žmogaus $\mathrm{Su}$ nus paduotas bus i žmoniu rankas, ir jie užmuš jĭ, ir užmuštas trečioje dienoje kelsis iš numirusiuju.

32 Ir jie to žodžio ne išmanė ir bijojos, jo klausti.

33 Ir jis atèjo i Kapernaumą. Ir namieje budamas, klausė jų: apie kągi jus ant kelio tarp savęs kalbẻjote?

34 Bet jie tylèjo. Nèsa jie tarp 
for by the way they had disputed among themselves, who should be the greatest.

35 And he sat down, and called the twelve, and saith unto them, If any man desire to be first, the same shall be last of all, and servant of all.

36 And he took a child, and set him in the midst of them : and when he had taken him in his arms, he said unto them,

37 Whosoever shall receive one of such children in my name, reeeiveth me: and whosoever shall receive me, receiveth not me, but nim that sent me.

38 I And John answered him. saying, Master, we saw one cast. ing out devils in thy name, and he followeth not us : and we forbad him, because he followeth not us.

39 But Jesus said, Forbid hinı not: for there is no man which shall do a miracle in my name, that can lightly speak evil of me.

40 For he that is not against us is on our part.

41 For whosoever shall give you a cup of water to drink in my name, because ye belong to Christ, verily I say unto you, he shall not lose his reward.

42 And whosoever shall offend one of these little ones that believe in me, it is better for him that a millstone were hanged about his neck, and he were cast into the sea.

43 And if thy hand offend thee, cut it off : it is better for thee to enter into life maimed, than savęs buvo ant kelio kalbẻję, kursai esąs didžiausiasis?

$35 \mathrm{Ir}$ jis pasisèdęs pasivadino anus dvylika ir tarè jiems: jei kas nor pirmiausiasis buti, tas bus paskiausiasis už visus, ir visu tarnas.

36 Ir èmęs kudikèli pastatè tą tarp jų, ir apsikabinęs ji tarè jiems:

37 Kas toki kudikèli mano vardan priima, tas manę priima; ir kas manę priima, ne manę priima, bet tą, kursai manę siuntęs.

38 Bet Jonas atsakẻ jam, tarydamas: mokịtojau, mes regèjome vieną tavo vardan velnius išvarantị, kursai mus ne sekė; ir mes jam tai gynėme, todèl, kad ne sekè mus.

39 Bet Jèzus tarè: ne ginkite jam; nẻs nei vieno niera, kursai darytu stebukla mano vardan, ir galètu tuojaus piktai apie manę kalbèti.

40 Kas ne prieš mus yra, tas yra su mumis.

41 Bet kas jus pagirdo vandens kupka mano vardan, dèl to, kad Kristaus este, iš tiesos aš jums sakau, ne pasiliks jam tai ne atpildyta.

42 Ir kas papiktina vieną šiı mažuju, i manę tikinčiuju, tam geriaus butu, kad jam girny akmuo ant kaklo užkabintas, ir jis i jures butu i̇mestas.

43 Bet jei tavę tavo ranka piktina, tai nukirsk ją. Geriaus tau yra, luošam ieiti i gyvatą, ne kaip kad 
having two hands to go into hell, into the fire that never shall be quenched:

44 Where their worm dieth not, and the fire is not quenched.

45 And if thy foot offend thee, cut it off : it is better for thee to enter halt into life, than having two feet to be cast into hell, into the fire that never shall be quenched:

46 Where their worm dieth not, and the fire is not quenched.

47 And if thine eye offend thee, pluck it out: it is better for thee to enter into the kingdom of God with one eye, than having two eyes to be cast into hell fire :

48 Where their worm dieth not, and the fire is not quenched.

49 For every one shall be salted with fire, and every sacrifice shall be salted with salt.

50 Salt is good: but if the salt have lost his saltness, wherewith will ye season it? Have salt in yourselves, and have peace one with another.

\section{CHAPTER $\mathrm{X}$.}

$A$ ND he arose from thence, and A cometh into the coasts of Judæa by the farther side of Jordan : and the people resort unto him again; and, as he was wont, he taught them again.

2 If And the Pharisees came to him, and asked him, Is it lawful for a man to put away his wife? tempting him.

3 And he answered and said unto them, What did Moses command you? tu, dvi ranki turèdamas, ieitumbei i peklą, i amžinąją ugni,

44 Kur ju kirmėlè ne miršta, ir ju ugnis ne užgesta.

45 Jei tave piktina tavo kojar nukirsk ją. Geriaus tau yra, raišam ieiti i gyvatą, ne kaip kad tu, abi koji turẻdamas, butumbei imestas i peklą, i amžinąją ugni,

46 Kur ju kirmèlè ne miršta, ir ju ugnis ne užgesta.

47 Jei tavę akis tavo piktina, atmesk ją nuog savęs. Geriaus tau yra, su viena akia iceiti i Dievo karalystę, ne kaip tu, dvi aki turèdamas, imestas butumbei i peklos ugni,

48 Kur ju kirmèlè ne miršta, ir jų ugnis ne užgesta.

49 Vislab tur ugnimi sudyta buti, ir kiekviena apiera druska sudoma yra.

50 Druska gera yra; bet jei druska surumą pameta, kuomi sudysime? turèkite druskos savipi, ir turẻkite pakaju tarp savęs.

\section{PERSKYRIMAS $\mathrm{X}$.}

$T^{R}$ jis pasikèlęs iš ten, atējo i šalis Žydų žemès anašal Jordano. Ir žmonès vèl pulkais èjo pas $\mathrm{ji}$, ir jis pagal savo paproti vèl juos mokino.

2 Ir Parizèušiai atẻje pas ji, klausė jo: bau vyrui vale esant, skirtis nuo savo pačios? Ir tuomi ji gundè.

3 Bet jis atsakydamas tarè: ką jums Maižěšius prisakè? 
St. MARK, X.

4 And they said, Moses suffered to write a bill of divorcement, and to put her away.

5 And Jesus answered and said unto them, For the hardness of your heart he wrote you this precept.

6 But from the beginning of the creation God made them male and female.

7 For this cause shall a man leave his father and mother, and cleave to his wife;

8 And they twain shall be one fiesh : so then they are no more twain, but one flesh.

9 What therefore God hath joined together, let not man put asunder.

10 And in the house his disciples asked him again of the same matter.

11 And he saith unto them, Whosoever shall put away his wife, and marry another, committeth adultery against her.

12 And if a woman shall put away her husband, and be married to another, she committeth adultery.

13 I And they brought young children to him, that he should touch them: and his disciples rebuked those that brought them.

14 But when Jesus saw it, he was much displeased, and said unto them, Suffer the little children to come unto me, and forbid them not: for of such is the kingdom of God.

15 Verily I say unto you, Whosoever shall not receive the kingdom of God as a little child, he shall not enter therein.

16 And he took them up in his

\section{EV. MARKOŠIAUS, X.}

4 Jie tarè: Maižěšius pavelijo parašyti atsiskyrimo gromata ir skirtis nuo jos.

5 Jèžus atsakydamas tarè jiems: dèl jusu širdies kietumo jis jums tą prisakyma parašè.

6 Ale iš pradžios sutvèrimo Dievas juodu sutvėrè vyrą bei moterị.

7 Todèl žmogus savo tẻvą ir motyną palikęs, prie savo moters glausis.

$8 \mathrm{Ir}$ bus juodu vienas kunas. Taipogi juodu ne yra du, bet vienas kunas.

9 Taigi, ką Dievas suvedęs, žmogus ne tur perskirti.

10 Ir namieje vèl klausẻ ji jo mokịtiniai apie tatai.

11 Ir jis tarè jiems: kurs skiriasi nuo savo pačios ir kita veda, tas peržengia venčiavonystę prieš ją.

12 Ir jei moteriškè skiriasi nuo savo vyro ir už kito eiti, ta peržengia savo venčiavonystę.

13 Ir jie prinešè kudikèliu pas ji, kad juos pakrutintu. Bet mokitiniai barè atnešančiuosius.

14 Bet Jèzus tai išvydęs, pykteréjo ir tarė jiems: leiskite kudikẻlius pas manę ateiti, ir ne drauskite jiems; nẻs tokių yra dangaus karalystè.

15 Iš tiesos sakau jums: jei kas dangaus karalyste ne priims kaip kudikèlis, tas ne ieis i ją.

16 Ir jis juos apsikabinęs, bei 
arms, put his hands upon them, and blessed them.

17 I And when he was gone forth into the way, there came one running, and kneeled to him, and asked him, Good Master, what shall I do that I may inherit eternal life?

18 And Jesus said unto him, Why callest thou me good? there is none good but one, that is, God.

19 Thou knowest the commandments, Do not commit adultery, Do not kill, Do not steal, Do not bear false witness, Defraud not, Honour thy father and mother.

20 And he answered and said unto him, Master, all these have I observed from my youth.

21 Then Jesus beholding him loved him, and said unto him, One thing thou lackest: go thy way, sell whatsoever thou hast, and give to the poor, and thou shalt have treasure in heaven : and come, take up the cross, and follow me.

22 And he was sad at that saying, and went away grieved : for he had great possessions.

23 And Jesus looked round about, and saith unto his disciples, How hardly shall they that have riches enter into the kingdom of God!

24 And the disciples were astonished at his words. But Jesus answereth again, and saith unto them, Children, how hard is it for them that trust in riches to enter into the kingdom of God!

$25 \mathrm{It}$ is easier for a camel to go savo rankas ant jụ uždẻjęs, peržegnojo juos.

17 Ir jam išèjus ant kelio, viens pirma bègo, klaupėsi jam ir klausẻ jo: gers mokitojau, ką darysu, kad amžinąją gyvatą i dalykus gaučiau?

18 Bet Jèzus tarè jam: kodèl tu manę vadini geru? nei viens ne esti geras, kaip tiktai vienas Dievas.

19 Juk žinai prisakymus: Ne peržengk venčiavonystès. Ne užmušk. Ne vogk. Ne liudyk neteisaus liudymo. Nieko ne prigauk. Garbink savo tèvą ir motyną.

20 Bet jis atsakydamas tarė jam: Mokịtojau, vislab tai dariau iš savo mazu dienų.

21 Ir Jézus pažiurèjęs i jị, mylèjo ji ir sakè jam: vieno dar tau reikia. Eik, parduok vislab, ką turi, ir duok ubagams, tai skarbą turèsi danguje; ir atéjęs sek manę, imdamas kryžiu ant savęs.

22 Bet jis apsismutnijęs dèl tos kalbos, atstojo nuliudęs; nès jis daug lobiu turèjo.

23 Ir Jèzus apsižvalgęs tarẻ savo mokitiniams: kaip sunkiai bagotieji ieis i Dievo karalystę!

24 Bet mokitiniai nusigando jo kalbos dẻlei. Bet Jèzus vẻl atsakydamas tarè jiems: mieli vaikai, kaip ne pigu yra, nusitikintiemsiems ant savo bagotystès ieiti $\mathfrak{i}$ Dievo karalystę!

25 Pigiaus yra verbludui pereiti 
through the eye of a needle, than for a rich man to enter into the kingdom of God.

26 And they were astonished out of measure, saying among themselves, Who then can be saved?

27 And Jesus looking upon them saith, With men it is impossible, but not with God: for with God all things are possible.

28 I Then Peter began to say unto him, Lo, we have left all, and have followed thee.

29 And Jesus answered and said, Verily I say unto you, There is no man that hath left house, or brethren, or sisters, or father, or mother, or wife, or children, or lands, for my sake, and the gos. pel's,

30 But he shall receive an hundredfold now in this time, houses, and brethren, and sisters, and mothers, and children, and lands, with persecutions; and in the world to come eternal life.

31 But many that are first shall be last; and the last first.

32 I And they were in the way going up to Jerusalem; and Jesus went before them : and they were amazed; and as they followed, they were afraid. And he took again the twelve, and began to tell them what things should happen unto him,

33 Saying, Behold, we go up to Jerusalem; and the Son of man shall be delivered unto the chief priests, and unto the scribes; and they shall condemn him to death, and shall deliver him to the Gentiles :

34 And they shall mock hin, pro adatos ausi, ne kaip kokiam bagotam ieiti i Dievo karalystę.

26 Bet jie juo daugiaus nusigando ir kalbėjo tarp savęs: kasgi tai gal išganytas pastoti?

27 Bet Jèzus í juos žiurẻdamas, tarè: žmonèms tai ne galima, bet ne Dievui; nėsa Dievui visi daiktai galimi.

28 Tai sakè jam Petras: štai, mes vislab palikę pasekẻme tavę.

29 Jèzus atsakydamas tarè: iš tiesos sakau jums: ne yra nei vieno, jei jis paliktu namus arba brolius arba seseris arba tėvą arba motyną arba moteri arba vaikus arba laukus dèl manęs ir dèl èvangẻlios,

30 Kurs ne igytų šimteropai, dabar šime čèse namus ir brolius ir seseris ir motynas ir vaikus ir laukus su persekinèjimais, iraname busiančiame amžyje amžynąją gyvatą.

31 Bet daug bus paskučiausieji, kurie yra pirmieji; ir bus pirmieji, kurie yra paskučiausieji.

32 Bet jie buvo ant kelio, užeidami i Jèruzalę; ir Jèzus pirm jų ejo, ir jie nusigando, sekẻ ji ir bijojos. Ir Jèzus vèl èmęs anus dvylika pas savę, sakè jiems, kas jam nusitiksią:

33 Štai, mes einam aukštyn i Jẻruzalę, ir žmogaus Sunus bus paduotas vyresniemsiems kunigams ir raštemokittiemsiems, ir jie prasudys ji ant smerties ir išduos $\mathrm{ji}$ pagonams.

34 Tie ji apjuoks ir nuplaks ir 
St. MARK, X.

and shall scourge him, and shall spit upon him, and shall kill him : and the third day he shall rise again.

35 I And James and John, the sons of Zebedee, come unto him, saying, Master, we would that thou shouldest do for us whatsoever we shall desire.

36 And he said unto them, What would ye that I should do for you?

37 They said unto him, Grant unto us that we may sit, one on thy right hand, and the other on thy left hand, in thy glory.

38 But Jesus said unto them, Ye know not what ye ask: can ye drink of the cup that I drink of? and be baptized with the baptism that I am baptized with?

39 And they said unto him, We can. And Jesus said unto them, Ye shall indeed drink of the cup that I drink of; and with the baptism that I am baptized withal shall ye be baptized :

40 But to sit on my right hand and on my left hand is not mine to give; but it shall be given to them for whom it is prepared.

41 And when the ten heard it, they began to be much displeased with James and John.

42 But Jesus called them to him, and saith unto them, Ye know that they which are accounted to rule over the Gentiles exercise lordship over them; and their great ones exercise authority upon them.

43 But so shall it not be among you: but whosoever will be great
EV. MARKOŠIAUS, $\mathbf{X}$.

apspiaudys ir užmuš, ir trečiąją dieną jis prisikelsis iš numirusiųjų.

35 Tai atẻjo pas ji Jokubas ir Jonas, Zebedẻjaus sunudu, tarydamu: Mokitojau, mudu noriva, kad mum darytumbei, ko tavęs prašysiva.

36 Jisai tarè jiemdviem: ko norita, kad jum daryčiau?

37 Juodu sakė jam: duok mumdviem sẻdèti, vienam po tavo dešinės, o antram po tavo kairės tavo šlovéje.

38 Ale Jèzus tarè jiemdviem: judu ne žinota, ko prašota. Argi galita gerti to kyliko, kuri aš geriu, ir tuomi krikštu krikštydintis, kuriuomi aš krikštijamas esmi?

39 Juodu sakè jam: galiva. Bet Jèzus tarè jiemdviem: kyliką tiesa gersita, kuri aš geriu, ir krikštu pakrikštytu busita, kuriuomi aš krikštijamas esmi;

40 Ale sẻdèti po mano dešinès ir po mano kairès, ne man puolasi jumdviem duoti, bet tiems, kuriems yra pagatavyta.

$41 \mathrm{Ir}$ tai išgirdę anie dešimt, pykterẻjo ant Jokubo ir Jono.

42 Bet Jèzus pasivadinęs juos, tarè jiems: jus žinote, svietiškuosius kunigaikščius viešpataujančius, ir galinguosius tarp ju macies turinčius;

43 Bet taipo ne tur buti tarp jųsu; bet kurs nor didžiu pastoti 
St. MARK, X. XI.

among you, shall be your minister :

44 And whosoever of you will be the chiefest, shall be servant of all.

45 For even the Son of man came not to be ministered unto, but to minister, and to give his life a ransom for many.

46 And they came to Jericho: and as he went out of Jericho with his disciples and a great number of people, blind Bartimæus, the son of Timæus, sat by the highway side begging.

47 And when he heard that it was Jesus of Nazareth, he began to cry out, and say, Jesus, thou son of David, have mercy on me.

48 And many charged him that he should hold his peace : but he cried the more a great deal, Thou son of David, have mercy on me.

49 And Jesus stood still, and commanded him to be called. And they call the blind man, say. ing unto him, Be of good comfort, rise; he calleth thee.

50 And he, casting away his garment, rose, and came to Jesus.

51 And Jesus answered and said unto him, What wilt thou that I should do unto thee? The blind man said unto him, Lord, that I might receive my sight.

52 And Jesus said unto him, Go thy way; thy faith hath made thee whole. And immediately he received his sight, and followed Jesus in the way.

\section{CHAPTER XI.}

$A$ ND when they came nigh to A Jerusalem, unto Bethphage
EV. MARKOŠIAUS, X. XI.

tarp jųsu, tasai bus jųsu tarnu;

44 Ir kas tarp jųsu nor vyriausiuoju buti, tas bus visu bernu.

45 Nès ir žmogaus Sunus ne atejo, kad sau duotųs šlužyti, bet kad jis šlužytı ir savo gyvasti duotụ atpirkimui už daug.

46 Ir jie atėjo i Jèriką. Ir kaip iš Jèrikos èjo, jis ir jo mokitiniai ir didè žmoniụ daugybè, tai sėdėjo aklas, Bartiméjus, Timėjaus sunus, pakelèje ubagaudamas.

47 Ir išgirdęs Jèzụ Nazarẻniški čia esanti, pradèjo jis šaukti ir tarti: Jèzau, tu sunau Dovido, susimilkis manęs!

48 Ir daug ji draudé, kad tylètu; ; bet jis juo daugiaus šaukè: Sunau Dovido, susimilkis manęs!

49 Ir Jẻzus apsistojęs liepẻ ji atvadinti; ir jie atvadino aklajji, sakydami jam: buk linksmas, kelkis, jis vadina tave.

$50 \mathrm{Ir}$ jis savo rubą nuo savęs pametè, ir kèlęsi atėjo pas Jèzų. $51 \mathrm{Ir}$ Jèzus atsakydamas tarẻ jamui: ko nori, kad tau daryčiau? Aklasis jam tarè: Mokįtojau, kad regèčiau.

52 Bet Jèzus sakè jam: eik, tavo tikejjimas tavę gelbèjo! Ir tuojaus jis galèjo regèti ir sekè ji ant kelio.

\section{PERSKYRIMAS XI.}

TR kaip jie prisiartino pas Jèruzalę, i Bètpagę ir Bètanią, 
and Bethany, at the mount of Olives, he sendeth forth two of his disciples,

2 And saith unto them, Go your way into the village over against you : and as soon as ye be entered into it, ye shall find a colt tied, whereon never man sat; loose him, and bring him.

3 And if any man say unto you, Why do ye this? say ye that the Lord hath need of him; and straightway he will send him hither.

4 And they went their way, and found the colt tied by the door without in a place where two ways met; and they loose him.

5 And certain of them that stood there said unto them, What do ye, loosing the colt?

6 And they said unto them even as Jesus had commanded: and they let them go.

7 And they brought the colt to Jesus, and cast their garments on him; and he sat upon him.

8 And many spread their garments in the way : and others cut down branches off the trees, and strawed them in the way.

9 And they that went before, and they that followed, cried, saying, Hosanna; Blessed is he that cometh in the name of the Lord:

10 Blessed be the kingdom of our father David, that cometh in the name of the Lord: Hosanna in the highest.

11 And Jesus entered into Jerusalem, and into the temple: and when he had looked round about upon all things, and now the eventide was come, he went out unto Bethany with the twelve. pas alyvu kalną, nusiuntẻ Jèzus du savo mokịtinių,

2 Ir tarè jiemdviem: nueikita $i$ miesteli, jumdviem po akiu esanti, ir tuojaus jejusiu, tenai rasita asilaiti pririštą, ant kurio niekados nei viens žmogus ne sèdėjęs; atrišusiu tą šen atveskita.

3 Ir jei jumdviem kas sakytų: kam tai darota? tai sakykita: Viešpats jo privalo; tai tuojaus ji šen atsiųs.

4 Juodu nuèjusiu rado asilaiti pririštą prie durų lauke, kur kelias skiriasi; ir atrišo ji.

5 Ir keli iš anų, kurie ten stovẻjo, tarẻ jiemdviem: ką darota, asilaiti atrišdamu?

6 Bet juodu atsakẻ jiems, kaip jiemdviem Jèzaus isakyta buvo; ir jie pavelijo tai.

7 Ir atvedusiu asilaiti pas Jèzụ, uždejjo ant jo savo rubus, ir jis užsisèdo ant to.

8 Bet daug paklojo savo rubus ant kelio; kiti verbas kirto nuo medžių, ir barstė tas ant kelio.

9 Ir kurie pirma ir paskui èjo, šaukè sakydami: Oziana, pašlovintas te esie, kursai ateiti vardan Viešpaties.

10 Pašlovinta te esie karalystè musu tèvo Dovido, kuri ateiti vardan Viešpaties! Oziana aukštybèje!

11 Ir Viešpats ièjo i Jèruzalę ir i bažnyčią, ir peržiurèjo vislab, ir vakare išejo jis i Bètanią su anais dvylika. 
12 I And on the morrow, when they were come from Bethany, he was hungry:

13 And seeing a fig tree afar off having leaves, he came, if haply he might find any thing thereon : and when he came to it, he found nothing but leaves; for the time of figs was not yet.

14 And Jesus answered and said unto it, No man eat fruit of thee hereafter for ever. And his disciples heard it.

15 I And they come to Jerusalem: and Jesus went into the temple, and began to cast out them that sold and bought in the temple, and overthrew the tables of the moneychangers, and the seats of them that sold doves;

16 And would not suffer that any man should carry any vessel through the temple.

17 And he taught, saying unto them, Is it not written, $\mathrm{My}$ house shall be called of all nations the house of prayer? but ye have made it a den of thieves.

18 And the scribes and chief priests heard it, and sought how they might destroy him : for they feared him, because all the people was astonished at his doctrine.

19 And when even was come, he went out of the city.

20 I And in the morning, as they passed by, they saw the fig tree dried up from the roots.

21 And Peter calling to remembrance saith unto him, Master, behold, the fig tree which thou cursedst is withered away.

22 And Jesus answering saith unto them, Have faith in God.
12 Ir antrajją dieną jiems išẻjus iš Bẻtanios, buvo jis išalkęs.

13 Ir pamate iš tolo pygu medị, lapus turinti; tai jis priejo prie to, bau ką ant jo rastų. Ir prièjęs, nieko ne rado, kaip tikt vienus lapus; nèsa dar ne buvo čèsas pygoms buti.

$14 \mathrm{Ir}$ atsakydamas Jèzus taré jam: taigi nieks te ne valgo daugiaus nuo tavęs nei jokio vaisiaus amžinai. Ir jo mokitiniai tai girdèjo.

15 Ir jie atėjo i Jèruzalę; ir Jèzus ịejęs i bažnyčią, pradèjo laukan varyti parduodančiuosius ir perkančiuosius bažnyčioje; ir parvertė stalus pinigmainiu, ir krèslus karvelius parduodančiuju;

16 Ir ne perleido nei vienam, ka nešti per bažnyčią.

$17 \mathrm{Ir}$ jis mokino, sakydamas jiems: ar ne parašyta yra: mano namai bus vadinami maldu namai visiems žmonèms? bet jus padarète iš ju razbaininku duobę.

18 Ir tai išgirdę raštemokịtieji ir vyriausieji kunigai, jèškojo, kaip ji nužudytú. Bet bijojosi jo; nèsa visi žmonès stebėjosi jo pamokslo.

19 Ir ant vakaro išejo jis laukan iš miesto.

$20 \mathrm{Ir}$ ryto meta praeidami, išvydo jie pygu medi padžiuvusi iki šaknių.

21 Ir Petras atsiminęs to, sakè jam: Mokitojau, štai, pygu medis, kuri prakeikei, padžiuvęs.

22 Jèzus atsakydamas tarẻ jiems: tikèkite i Dievą. 
ST. MARK, XI.

23 For verily I say unto you, That whosoever shall say unto this mountain, Be thou removed, and be thou cast into the sea; and shall not doubt in his heart, but shall believe that those things which he saith shall come to pass; he shall have whatsoever he saith.

24 Therefore I say unto you, What things soever ye desire, when ye pray, believe that ye receive them, and ye shall have them.

25 And when ye stand praying, forgive, if ye have ought against any : that your Father also which is in heaven may forgive you your trespasses.

26 But if ye do not forgive, neither will your Father which is in heaven forgive your trespasses.

27 I And they come again to Jerusalem : and as he was walking in the temple, there come to him the chief priests, and the scribes, and the elders,

28 And say unto him, By what authority doest thou these things? and who gave thee this authority to do these things?

29 And Jesus answered and said unto them, I will also ask of you one question, and answer me, and I will tell you by what authority I do these things.

30 The baptism of John, was it from heaven, or of men? answer me.

31 And they reasoned with themselves, saying, If we shall say, From heaven; he will say, Why then did ye not believe him?

32 But if we shall say, of men; they feared the people: for all
EV. MARKOŠIAUS, XI.

23 Iš tiesos sakau jums: kas šiam kalnui sakytų: pasikelk ir isiversk $i$ jures, ir ne abejoty savo širdyje, bet tikëtu, nusiduosiant, ką jis sako, tai nusiduos jam tai, ka jis sako.

24 Togidèl sakau jums: vislab ka jus meldžiate savo maldoje, tikt tikèkite, gausią, tai bus jums.

25 Ir kad stovite melsdamiesi, tai atleiskite, jei ka turite prieš kitą, kad ir jųsu Tèvas danguje jums atleistų jųsu nusidéjimus.

26 Bet jei jus ne atleisite, tai ir jussu Tévas dangujęsis jums ne atleis jųsu nusidèjimus.

27 Ir jie vèl atėjo i Jèruzalę. Ir jam i bažnyčią iejjus, atẻjo pas ji vyriausieji kunigai ir raštemokitieji ir vyresnieji,

28 Ir tarè jam: kokioje macieje tu tai darai? ir kas tau sita maci davè, kad tai darytumbei?

29 Bet Jèzus atsakydamas tarz jiems: ir aš paklausu jus vienė žodị; atsakykite man, tai jums sakysu, kokioje macieje aš tai darau.

30 Jono krikštas, ar tas iš dangaus buvo, ar iš žmonių? atsakykite man!

31 Ir jie dumojo savyje tarydami: jei sakome, ji iš dangaus buvusi, tai jis sakys: kodèlgi jus jam ne vierijote?

32 Bet jei sakome, ji iš žmoniu buvusi, tai žmonių bijomės; nẻsa 
St. MARK, XI. XII.

men counted John, that he was a prophet indeed.

33 And they answered and said unto Jesus, We cannot tell. And Jesus answering saith unto them, Neither do I tell you by what authority I do these things.

\section{CHAPTER XII.}

$A$ ND he began to speak unlo A them by parables. A certain man planted a vineyard, and set an hedge about it, and digged a place for the winefat, and built a tower, and let it out to husbandmen, and went into a far country.

2 And at the season he sent to the husbandmen a servant, that he might receive from the husbandmen of the fruit of the vineyard.

3 And they caught him, and beat him, and sent him awry empty.

4 And again he sent unto them another servant; and at him they cast stones, and wounded him in the head, and sent him away shamefully handled.

5 And again he sent another; and him they killed, and many others; beating some, and killing some.

6 Having yet therefore one son, his wellbeloved, he sent him also last unto them, saying, They will reverence my son.

7 But those husbandmen said among themselves, This is the heir; come, let us kill him, and the inheritance shall be our's.

8 And they took him, and killed him, and cast him out of the vineyard.
EV. MARKOŠIAUS, XI. XII.

visi laikẻ Joną per tikrą praraką.

33 Ir atsakydami tarè Jèzui: meto ne žinome. Ir Jèzus atsakys damas tarè jiems: tai ir aš jums ne sakau, kokioje macieje aš tai darau.

\section{PERSKYRIMAS XII.}

TR jis pradejjo jiems per prilyginimus kalbèti: žmogus sodino vynyčią, ir tą aptvèré tvora, ir iškasè vyno spaustuvę, ir pabudavojo korą, ir parsamdęs tą vynyčininkams, i svetiuną žemę iškeliavo.

2 Ir nusiuntè vieną tarną, čésui atėjus, pas vynyčininkus, kad jis nuog vynyčininku imty vynyčios vaisių.

3 Bet jie nutve̊re̊ ji, nuplakẻ ji ir ji tuščia nuog savęs paleido.

4 Ir vẻl nusiuntè jis pas juos kitą tarną; to galva jie akmenimis sukulé, ir apgédintą paleido nuo savęs.

5 Ir vèl jisai nusiuntė kitą; tą jie užmušè, ir daug kitu, kitus jie nuplakè, kitus nužavino.

6 Tai jis turẻdamas vičviena sunu, kurs jo mylimas buvo, tą jis paskiaus nusiuntè taipojau pas juos, sakydamas: jie bijosis mano sunaus.

7 Bet tie vynyčininkai susikalbèjo: tai tèvonis; eikim ir užmuškim ji, tai musụ bus tẻviškè.

8 Ir jie èmę ji užmušè ir laukan išmetẻ iš vynyčios. 
St. MARK, XII.

9 What shall therefore the lord of the vineyard do? he will come and destroy the husbandmen, and will give the vineyard unto others.

10 And have ye not read this scripture; The stone which the builders rejected is become the head of the corner :

11 This was the Lord's doing, and it is marvellous in our eyes? 12 And they sought to lay hold on him, but feared the people : for they knew that he had spoken the parable against them: and they left him, and went their way.

13 I And they send unto him certain of the Pharisees and of the Herodians, to catch him in his words.

14 And when they were come, they say unto him, Master, we know that thou art true, and carest for no man: for thou regardest not the person of men, but teachest the way of God in truth : Is it lawful to give tribute to Cæsar, or not?

15 Shall we give, or shall we not give? But he, knowing their hypocrisy, said unto them, Why tempt ye me? bring me a penny, that $I$ inay see $i t$.

16 And they brought it. And he saith unto them, Whose is this image and superscription? And they said unto him, Cæsar's.

17. And Jesus answering said unto them, Render to Cæsar the things that are Cæsar's, and to God the things that are God's. And they marvelled at him.

18 if Then come unto him the Sadducees, which say there is no resurrection; and they asked him, saying,
EV. MARKOŠIAUS, XII.

9 Kągi ponas tos vynyčios darys? jisai atèjęs nužudys tus vynyčininkus, ir vynyčią kitiems duos.

$10 \mathrm{Ar}$ ne skaitète ir šitą raštą: Akmuo, kuri budavonininkai atmetè, tas kampiniu akmenimi pastojo?

11 Nuog Viešpaties tai tikosi, ir dyvas yra musu akyse.

12 Ir jie jěškojo, kaip ji sugautu, (o tačiau žmoniu bijojosi,) nèsa jie suprato, ji tus prilyginimus ant ju kalbèjusi; ir ji palikę, atstojo.

13 Ir jie nusiuntè pas ji kelis iš Parizèušiu ir Erodo tarnų, kad ji sugautu kalboje.

14 Ir jie atėję tarè jam: Mokitojau, žinome, tave teisu esanti, ir nei vieno ne atbojanti, nèsa tu ne veizdi nei šiokio, nei tokio žmogaus, bet kelia Dievo teisiai mokini. Ar vert, čyžę duoti ciecoriui, ar ne? ar jam duosim, ar ne duosim?

15 Bet jis supratęs ju veidmainystę, tarè jiems: kam manę gundote? atneškite man graši, kad ji matyčiau.

16 Ir jie atnešè jam. Tai jis tarè: kieno tai abrozas ir užrašas? anie jam sakè: ciecoriaus.

17 Tai atsakydamas Jèzus tarè jiems: taigi duokite ciecoriui, kas ciecoriaus, ir Dievui, kas Dievo yra. Ir jie dyvijosi jo.

18 Tai atėjo pas ji Saducẻušiai, (kurie sako, ne esant prisikèlimo iš numirusiųju,) tie ji klausè, sakydami: 
St. MARK, XII.

19 Master, Moses wrote unto us, If a man's brother die, and leave his wife behind him, and leave no children, that his brother should take his wife, and raise up seed unto his brother.

20 Now there were seven brethren: and the first took a wife, and dying left no seed.

21 And the second took her, and died, neither left he any seed: and the third likewise.

22 And the seven had her, and left no seed : last of all the woman died also.

23 In the resurrection therefore, when they shall rise, whose wife shall she be of them? for the seven had her to wife.

24 And Jesus answering said unto them, Do ye not therefore err, because ye know not the scriptures, neither the power of God?

25 For when they shall rise from the dead, they neither marry, nor are given in marriage; but are as the angels which are in heaven. 26 And as touching the dead, that they rise: have ye not read in the book of Moses, how in the bush God spake unto him, saying, I am the God of Abraham, and the God of Isaac, and the God of Jacob?

$27 \mathrm{He}$ is not the God of the dead, but the God of the living : ye therefore do greatly err.

28 I And one of the scribes eame, and having heard them reasoning together, and perceiving that he had answered them well, asked him, Which is the first commandment of all?
EV. MARKOŠIAUS, XII.

19 Mokitojau, Maižěšius mums parašè: jei kieno brolis numirdamas paliekti moteri, ir ne paliekti vaiku, kad tai jo brolis paimty jo pačią, ir savo broliui sėklos pagamintu.

20 Bet dabar septyni broliai yra buvę. Pirmasis émé moteri; tasai mirdamas ne paliko vaikų.

$21 \mathrm{Ir}$ antrasis ją paèmęs pasimiré, o ir tas taipojau ne paliko vaiku. Taipojau ir trečiasis.

22 Ir tą paèmè visi septyni, ir ne paliko vaiku. Galiausiai po visu numirè ir ta moteriškè.

23 Taigi prisikèlime iš numirusiuju, kad jie kelsis, kurio ji bus pati iš tų? nẻsa septyni ją per pačią turéjo.

24 Tai atsakydamas Jèzus taré jiems: ar ne taipo? jus klajojate, todèl, kad nieko ne žinote, nei apie raštą, nei apie maci Dievo.

$25 \mathrm{Kad}$ jie iš numirusiuju kelsis, tai jie nei ves, nei tekẻs, bet jie yra kaip angielai danguje.

26 Bet apie numirusiuosius, juos prisikelsiant, ar ne skaitète knygose Maižěšiaus, pas krumą, kaip jam Dievas kalbèjo ir tarè: Ǎs esmi Dievas Abraomo, ir Dievas Izaoko, ir Dievas Jokubo.

27 O Dievas ne numirusiuju, bet gyvuju Dievas. Togidèl jus labai klajojate.

28 Ir priējęs ji vienas iš raštemokịtuju, kursai jụ įsiklausęs buvo, kaip jie tarp savęs klausinèjosi, regèdamas, kaip jis jiems mandagiai atsakęs buvo, klausè jokurs yra visu vyriausysis prisa: kymas? 
St. MARK, XII.

29 And Jesus answered him, The first of all the commandments is, Hear, O Israel; The Lord our God is one Lord :

30 And thou shalt love the Lord thy God with all thy heart, and with all thy soul, and with all thy mind, and with all thy strength : this is the first commandment.

31 And the second is like, namely this, Thou shalt love thy neighbour as thyself. There is none other commandment greater than these.

32 And the scribe said unto him, Well, Master, thou hast said the truth : for there is one God; and there is none other but he :

33 And to love him with all tho heart, and with all the understanding, and with all the soul, and with all the strength, and to love his neighbour as himself, is more than all whole burnt offerings and sacrifices.

34 And when Jesus saw that he answered discreetly, he said unto him; Thou art not far from the kingdom of God. And no man after that durst ask him any ques. tion.

35 I And Jesus answered and said, while he taught in the temple, How say the scribes that Christ is the Son of David?

36 For David himself said by the Holy Ghost, The Lond said to my Lord, Sit thou on my right hand, till I make thine enemies thy footstool.

37. David therefore himself calleth him Lord; and whence is he then his son? And the common people heard him gladly.
EV. MARKOŠIAUS, XII.

29 Bet Jèzus atsakẻ jam: vyriausysis prisakymas iš visu prisakymu tas yra: klausyk Izraèl, Viešpats, musu Dievas, yra vienas vienatijis Dievas;

30 Ir mylẻk Dievą, savo Viešpatị, iš visos širdies, iš visos dušios, iš viso umo, ir iš visos savo sylos; tai yra vyriausysis prisakymas.

31 Ir antrasis tamui yra lygus: mylèk savo artymą, kaip pats savę. Niera nei jokio kito didesnio prisakymo per šitus.

32 Ir raštemokịtasis tarẻ jam: Mokịtojau, iš tiesos gerai atsakei; nësa vienas Dievas yra, ir niera kito per $\mathrm{ji}$.

33 Ir tą mylèti iš visos širdies, iš viso umo, iš visos dušios, ir iš visos sylos, ir mylèti savo artymą, kaip save pati, tai daugiaus yra už visas deginimo apieras ir už visas apieras.

34 Bet Jèzus regèdamas, aną išmintingai atsakiusi, taré jam: tu ne toli esi nuog Dievo karalystès. Ir nei vienas ne drịso, jo toliaus klausti.

35 Ir Jèzus atsakydamas tarè, mokindamas bažnyčioje: kaipo sako raštemokitieji, Kristų esanti Dovido sunį?

36 Bet jis, Dovidas, per šventaja Dvase sako: Viešpats sakẻ mano Viešpačiui: sèskis po mano dešinès, koliai padèsu tavo neprietelius suoleliu tavo kojų.

37 Cia juk Dovidas ji vadina savo Viešpatimi, kaipogi tai jis yra jo sunus? Ir daug žmonių mielai jo klausėsi. 
ST. MARK, XII. XIII.

38 I And he said unto them in his doctrine, Beware of the scribes, which love to go in long clothing, and love salutations in the marketplaces,

39 And the chief seats in the synagogues, and the uppermost rooms at feasts :

40 Which devour widows' houses, and for a pretence make long prayers : these shall receive greater damnation.

41 I And Jesus sat over against the treasury, and beheld how the people cast money into the treasury: and many that were rich cast in much.

42 And there came a certain poor widow, and she threw in two mites, which make a farthing.

43 And he called unto him his disciples, and saith unto them, Verily I say unto you, That this poor widow hath cast more in, than all they which have cast into the treasury :

44 For all they did cast in of their abundance; but she of her want did cast in all that she had, even all her living.

\section{CHAPTER XIII.}

ND as he went out of the temA ple, one of his disciples saith unto him, Master, see what man. ner of stones and what buildings are here!

2 And Jesus answering said unto him, Seest thou these great buildings? there shall not be left one stone upon another, that shall not be thrnwn down.

3 And as he sat upon the mount of Ulives over against the temple,
EV. MARKOŠIAUS, XII. XIII.

38 Ir jis mokindamas juos, tarè jiems: saugokitẻs nuog raštemokịtuju, kurie ilgus rubus dẻvia, ir mielai ant turgaus sveikindinasi,

39 Ir meilija sẻdèti vyriausiose vietose mokyklose, ir už stalo česnyse;

40 Jie praryja našliu namus ir sakosi, ilgas maldas meldžiantis. Tiems bus juo didesnis pražudymas.

41 Ir Jèzus pasisèdęs ties bažnyčios skrynia regejo, kaipo žmonẻs pinigu idejejo i bažnyčios skrynią. Ir daug bagoty daug idejjo.

42 Ir atéjusi viena našlè vargdienè, i̇dèjo du juodikiu; tuodu padaro vieną pinigèli.

$43 \mathrm{Ir}$ jis pasivadinęs savo mokịtinius, tarè jiems: iš tiesos sakau jums, ši vargingoji našlè daugiaus iddẻjo i bažnyčios skrynią už visus, kurie idejjo.

44 Nèsa jie visi i̇dejo nuog savo apstumo, ale ši nuog savo ubagystès, vislab, ką turèjo, visą savo išlaikymą, i̇dèjo.

\section{PERSKYRIMAS XIII.}

TR jam išeinant iš bažnyčios, sakẻ jam vienas jo mokitiniu: Mokịtojau, veizdèk, kokie tai akmens ir kokia tai budavonè yra!

2 Ir Jèzus atsakydamas tarè jam: begu matai šitą visą didę budavonę? nei akmuo ant akmens ne pasiliks ne sugriautas.

3 Ir se̊dint jamui ant alyvy kalno ties bažnyčia, klausẻ ji sky 
St. MARK, XIII.

Peter and James and John and Andrew asked him privately,

4 Tell us, when shall these things be? and what shall be the sign when all these things shall be fulfilled?

5 And Jesus answering them began to say, Take heed lest any man deceive you :

6 For many shall come in my name, saying, I am Christ; and shall deceive many.

7 And when ye shall hear of wars and rumours of wars, be ye not troubled: for such things must needs be; but the end shall not be yet.

8 For nation shall rise against nation, and kingdom against kingdom: and there shall be earthquakes in divers places, and there shall be famines and troubles: these are the beginnings of sorrows.

9 I But take heed to yourselves: for they shall deliver you up to councils: and in the synagogues ye shall be beaten: and ye shall be brought before rulers and kings for my sake, for a testimony against them.

10 And the gospel must first be published among all nations.

11 But when they shall lead you, and deliver you up, take no thought beforehand what ye shall speak, neither do ye premeditate : but whatsoever shall be given you in that hour, that speak ye : for it is not ye that speak, but the Holy Ghost.

12 Now the brother shall betray the brother to death, and the
EV. MARKOŠIAUS, XIII.

riu Petras ir Jokubas ir Jonas ir Endrëjus:

4 Pasakyk mums, kada tai bus? ir koks bus ženklas, kada tai vislab turès nusiduoti?

5 Jèzus atsakydamas jiems, pradẻjo sakyti: dabokitẻs, kad jus ne kas suklastuotu!

6 Nèsa daug ateis mano vardan, sakydami: aš esmi Kristus; ir daugumą suklastuos.

7 Bet kad jus išgirsite karus ir šauksmus apie karus, tai nesibijokite; nès taip tur buti. Bet dar ne yra galas.

8 Sukils žmonès prieš žmones, ir karalystè prieš karalystę, ir bus žemès drebėjimai šen ir ten, ir bus badai ir išgąsčiai. Tai bẻdos yra pradžia.

9 Bet jus saugokitès! Nèsa jus paduos rotai ir mokykloms, ir jus turite buti plakti, ir pas kunigaikščius bei karalius turite buti vesti dèl manęs, liudymui ant jų.

10 Ir Evangẻlia tur pirma apsakyta buti tarp visų žmonių giminių.

11 Taigi, kad jie jus ves ir paduos, tai nesirupikitès, ką jums reikia kalbėti, nei pirma apsimislykitès; bet kas jums tą pačią adyną bus duota, tai kalbèkite; nès ne jus este, kurie kalbate, bet šventoji Dvasè.

12 Bet brolis paduos broli ant smerties, ir tèvas sunų, ir vaikai 
father the son; and children shall rise up against their parents, and shall cause them to be put to death.

13 And ye shall be hated of all men for my name's sake : but he that shall endure unto the end, the same shall be saved.

14 I But when ye shall see the abomination of desolation, spoken of by Daniel the prophet, standing where it ought not, (let him that readeth understand,) then let them that be in Judæa flee to the mountains :

15 And let him that is on the housetop not go down into the house, neither enter therein, to take any thing out of his house : 16 And let him that is in the field not turn back again for to take up his garment.

17 But woe to them that are with child, and to them that give suck in those days!

18 And pray ve that your flight be not in the winter.

19 For in those days shall be affliction, such as was not from the beginning of the creation which God created unto this time, neither shall be.

20 And except that the Lord had shortened those days, no flesh should be saved: but for the elect's sake, whom he hath chosen, he hath shortened the days.

21 And then if any man shall say to you, Lo, here is Christ; or, lo, he is there; believe him not:

22 For false Christs and false prophets shall rise, and shall shew signs and wonders, to seduce, if it were possible, even the elect. pasikels prieš gimdytojus, ir padès juos užmušti.

13 Ir busite ne apkenčiami visu dẻl mano vardo. Bet kas ištrivos iki galo, tas bus išganytas.

14 Bet kad išvysite išpustijimo biaurybę, apsakytaja per praraka Dangièlą, stovinčią vietoje, kur ne pareitis, (tai skaitąsis te išmano,) tad, jei kas Judèoje yra, te bèga ant kalnu;

15 Ir jei kas ant stogo yra, tas te ne nukopa i butą, ir te ne ieina, ką gabentis iš savo namų.

16 Ir kas ant lauko yra, tas te ne grišta atgalios, savo rubu imtis.

17 Bet bẻda néščioms ir žindančioms tuo čèsu.

18 Bet melskite, kad jums ne tektų bẻgti žiemoje.

19 Nès bus tose dienose tokie vargai kokie ikšioliai nei bute ne buvo nuog pradžios sutvėrimu, kurius Dievas sutvẻręs, ir kokių nei bute ne bus.

$20 \mathrm{Ir}$ jei Viešpats tas dienas ne batu patrumpinęs, tai nei vienas žmogus ne pastotu išganytas; bet dèl išrinktuju, kurius jis išsirinko, jis patrumpino tas dienas.

21 Jeigu tada kas jums tars: štai, čia yra Kristus, štai, tenai yra; tai ne vierykite.

22 Nèsa pasikelsis netikri Kristus ir netikri prarakai, dara ženklụ ir stebuklų, aža išvadžiotų, jei galima, ir išrinktuosius. 
ST. MARK, XIII.

23 But take ye heed : behold, I have foretold you all things.

24 II But in those days, after that tribulation, the sun shall be darkeved, and the moon shall not give her light,

25 And the stars of heaven shall fall, and the powers that are in heaven shall be shaken.

26 And then shall they see the Son of man coming in the clouds with great power and glory.

27 And then shall he send his angels, and shall gather together his elect from the four winds, from the uttermost part of the earth to the uttermost part of heaven.

28 Now learn a parable of the fig tree; When her branch is yet tender, and putteth forth leaves, ye know that summer is near:

29 So ye in like manner, when ye shall see these things come to pass, know that it is nigh, even at the doors.

30 Verily I say unto you, that this generation shall not pass, till all these things be done.

31 Heaven and earth shall pass away : but my words shall not pass away.

32 I But of that day and that hour knoweth no man, no, not the angels which are in heaven, neither the Son, but the Father.

33 Take ye heed, watch and pray : for ye know not when the time is.

34 For the Son of man is as a man taking a far journey, who left his house, and gave authority to his servants, and to every man his work, and commanded the porter to watch.
EV. MARKOŠIAUS, XIII.

23 Bet jus saugokitès! Štai, aš vislab jums pirma pasakiau.

24 Bet tame čése po to vargo saulè ir ménuo savo šviesybę pames;

25 Ir žvaigždès nuog dangaus puls, ir dangaus tvirtybès judissis.

26 Ir tad jie išvys žmogaus Sunų ateinanti debesyse, su dide stiprybe ir , šlove.

27 Ir tada jis siųs savo angielus, ir surinks savo išrınktuosius nuog keturiu vėjų, nuog žemès krašto, iki krašto dangaus.

28 Nuog pygu medžio mokịkitès prilyginimą: jo šakoms jau sprogstant ir lapams atsirandant, numanote, vasara artinantis.

29 Taipo ir jus, matydami tai nusiduodant, žinokite, tai arti už duru esant.

30 Iš tiesos sakau jums: ne sugaiš ta giminè, iki tam visam nusiduodant.

31 Dangus ir žemẻ sugaiš; bet mano žodžiai ne sugaiš.

32 Bet tą diena ir adyną nežino nieks, nei angielai danguje, nei Sunus, bet tiktai vienas Tẻvas.

33 Dabokitės, budẻkite ir melskitès; nėsa ne žinote, kada tas čèsas yra.

34 Lygiai kaip žmogus, kurs toli keliaudamas, paliko savo namus, ir valę davẻ savo bernams, kožnam jo darba, ir vartininkui prisaké, kad budètų. 
St. MARK, XIII. XIV.

35 Watch ye therefore: for ye know not when the master of the house cometh, at even, or at midnight, or at the cockcrowing, or in the morning :

36 Lest coming suddenly he find you sleeping.

37 And what I say unto you I say unto all, Watch.

\section{CHAPTER XIV.}

A FTER two days was the feast A of the passover, and of un. leavened bread: and the chief priests and the scribes sought how they might take him by craft, and put him to death.

2 But they said, Not on the feast $d a y$, lest there be an uproar of the people.

3 I And being in Bethany in the house of Simon the leper, as he sat at meat, there came a woman having an alabaster box of ointment of spikenard very precious; and she brake the box, and poured it on his head.

4 And there were some that had indignation within themselves, and said, Why was this waste of the ointment made?

5 For it might have been sold for more than three hundred pence, and have been given to the poor. And they murmured against her.

6 And Jesus said, Let her alone; why trouble ye her? she hath wrought a good work on me.

7 For ye have the poor with you always, and whensoever ye will ye may do them good: but me ye have not always.

8 She hath done what she could :
EV. MARKOŠIAUS, XIII. XIV.

35 Taigi budẻkite, (nèsa ne žinote, kada namu Viešpats ateis; ar jis ateis vakare, ar nakties viduryje, ar gaidgystèje, ar ryto meta.)

$36 \mathrm{Kad}$ ne, ateidamas staigiai, rastu jus be miegančius.

37 Bet ką aš jums sakau, tai sakau visiems: budèkit!

\section{PERSKYRIMAS XIV.}

TR po dviejų dienų buvo velykos ir dienos neraugintos duonos. Ir vyriausieji kunigai bei raštemokitieji jëškojo, kaip ji kytriai sugavę nužavintų.

2 Bet jie tarè: minau ne per šventę, kad maištas ne rastųs tarp žmonių.

3 Ir Jèzui esant Bètanioje, namuose Simono raupsuotojo, ir už stalo be sèdint, atẻjo moteriškè, turẻdama stiklą su nemaišytu ir brangiumi nardo vandenimi, ir ji sukulusi stiklą, užliejo tą ant jo galvos.

4 Tai keli buvo, tie pykterèjo, tarydami: kamgi tas pustijimas?

5 Butú galèję tą vandeni už daugiaus, ne kaip už tris šimtus grašiu parduoti, ir tai ubagams duoti. Ir murmèjo ant jos.

6 Bet Jèzus tarè: duokite jai pakaju, kodẻl ją raudinate? Ji tikrai gerai man padaré.

7 Ubagus visados turite pas savę, ir kad norite, galite jiems gero daryti; bet manę ne turite visados. $8 \mathrm{Ji}$ darè, ką galèjo; ji pasisku- 
she is come aforehand to anoint $\mathrm{my}$ body to the burying.

9 Verily I say unto you, Wheresoever this gospel shall be preached throughout the whole world, this also that she hath done shall be spoken of for a memorial of her.

10 q And Judas Iscariot, one of the twelve, went unto the chief priests, to betray him unto them.

I1 And when they heard it, they were glad, and promised to give him money. And he sought how he might conveniently betray him.

12 If And the first day of unleavened bread, when they killed the passover, his disciples said unto him, Where wilt thou that we go and prepare that thou mayest eat the passover?

13 And he sendeth forth two of his disciples, and saith unto them, Go ye into the city, and there shall meet you a man bearing a pitcher of water: follow him.

14 And wheresoever he shall go in, say ye to the goodman of the house, The Master saith, Where is the guestchamber, where I shall eat the passover with my disciples?

15 And he will shew you a large upper room furnished and prepared : there make ready for us.

16 And his disciples went forth, and eame into the city, and found as he had said unto them: and they made ready the passover.

17 And in the evening he cometh with the twelve.

18 And as they sat and did eat, Jesus said, Verily I say unto you, One of you which eateth with me shall betray me.

19 And they began to be sorrow- bino, mano kuną pamostyti ant mano palaidojimo.

9 Iš tiesos sakau jums: kur sakoma bus šita Evangẻlia per visą svietą, čia ir sakoma bus ant jos paminklo, ka ji dabar dariusi.

10 Ir Judošius Iškariotas, vienas iš tų dvylika, nuejo pas vyriausiuosius kunigus, kad ji išduotų. 11 Tai anie išgirdę prasidžiugo ir pasižadejjo, jam pinigu duoti. Ir jis ješkojo, kaip ji tropnai išduotu.

12 Ir pirmają dieną neraugintosios duonos, kaip velyku avinèli apieravojo, sakẻ jam jo mokitiniai: kur nori, kad mes nuẻje pagatavytumbime, kad velyku avinèli valgytumbei?

$13 \mathrm{Ir}$ jis nusiuntè du savo mokitiniu, ir tarè jiemdviem: eikita i miestą, ir sutiks judu žmogus, nešąs izboną vandens, tą sekita.

14 Ir kur jis ieis, čia tarkita gaspadoriui: Mokitojis tau sakydina, kur yra gaspada, kur aš galęčiau velyku avinèli valgyti su savo mokitiniais?

15 Ir jis parodys jum didele svetlyčią, išklotą ir prigatavytą; čia mums pagatavykita.

16 Ir pasiuntiniu išeję, atẻjo i miesta ir rado, kaip jis jiemdviem buvo sakęs, ir pagatavijo velyku avinèli.

17 Bet vakare atẽjo jis su tais dvylika.

18 Ir jiems už stalo be sèdint ir be valgant, tarè Jèzus: iš tiesos sakau jums, vienas jųsu, kurs su manimi valgo, išduos manę.

19 Ir anie nusismutniję, tarè jam 
ful, and to say unto him one by one, Is it I? and another said, Is it I?

20 And he answered and said unto them, It is one of the twelve, that dippeth with me in the dish.

21 The Son of man indeed goeth, as it is written of him : but woe to that man by whom the Son of man is betrayed! good were it for that man if he had never been born.

22 If And as they did eat, Jesus took bread, and blessed, and brake $i t$, and gave to them, and said, Take, eat: this is my body.

23 And he took the cup, and when he had given thanks, he gave it to them: and they all drank of it.

24 And he said unto them, This is my blood of the new testament, which is shed for many.

25 Verily I say unto you, I will drink no more of the fruit of the vine, until that day that I drink it new in the kingdom of God.

26 I And when they had sung an hymn, they went out into the mount of Olives.

27 And Jesus saith unto them, All ye shall be offended because of me this night : for it is written, I will smite the shepherd, and the sheep shall be scattered.

28 But after that I am risen, I will go before you into Galilee.

29 But Peter said unto him, Although all shall be offended, yet will not I.

30 And Jesus saith unto him, Verily I say unto thee, That this po kits kito: argi aš esmi? ir antras: argi aš esmi?

$20 \mathrm{Jis}$ atsakydamas tarẻ jiems: vienas iš dvylika, kursai su manimi i bliudą dažo.

21 Žmogaus sunus tiesa nueiti, kaipo apie ji parašyta; bet bẻda tam žmogui, per kuri žmogaus sunus išduotas bus! Geriaus butu tam žmogui, kad niekados ne butu gimęs.

22 Ir jiems be valgant, èmè Jèzus duoną, dèkavojo, laužé ir davè jiems, sakydamas: imkite, valgykite, tai esti mano kunas.

23 Ir èmęs kyliką, padèkavojo ir davẻ jiems tą, ir jie visi iš to gèrè.

$24 \mathrm{Ir}$ jis tarẻ jiems: tai yra mano kraujas naujojo testamento, kursai praliejamas už daugel.

25 Iš tiesos sakau jums: aš daugiaus ne gersu vaisiaus vynmedžio, iki anos dienos, kad gersu tą naują karalystēje Dievo.

26 Ir pagiedoję liaupsẻs giesmę, išèjo jie pas alyvų kalną.

27 Ir Jèzus tarè jiems: jus visi šią nakti manimi pasipiktisite. Nèsa parašyta yra: aš ištiksu ganytoji, ir avys išsisklaidys.

28 Bet prisikèlęs iš numirusiujju, aš pirm jųsu nueisu i Galilèą.

29 Ale Petras tarẻ jam: o kad ir visi pasipiktintų, aš tačiau ne pasipiktinčiau.

$30 \mathrm{Ir}$ Jèzus tarè jam: iš tiesos sakau tau: šiandien, šią naktị gai- 
day, even in this night, before the cock crow twice, thou shalt deny me thrice.

31 But he spake the more vehemently, If I should die with thee, I will not deny thee in any wise. Likewise also said they all.

32 And they came to a place which was named Gethsemane : and he saith to his disciples, Sit ye here, while I shall pray.

33 And he taketh with him Peter and James and John, and began to be sore amazed, and to be very heavy;

34 And saith unto them, My soul is exceeding sorrowful unto death : tarry ye here, and watch.

35 And he went forward a little, and fell on the ground, and prayed that, if it were possible, the hour might pass from him.

36 And he said, Abba, Father, all things are possible unto thee; take away this cup from me: nevertheless not what I will, but what thou wilt.

37 And he cometh, and findeth them sleeping, and saith unto Peter, Simon, sleepest thou? couldest not thou watch one hour?

38 Watch ye and pray, lest ye enter into temptation. The spirit truly is ready, but the flesh is weak.

39 And again he went away, and prayed, and spake the same words. 40 And when he returned, he found them asleep again, (for their eyes were heavy,) neither wist they what to answer him.

41 And he cometh the third time, and saith unto them, Sleep on now, and take your rest : it is džiui dar ne du kartu pragydus, tris kartus manęs užsigịsi.

31 Bet jis dar toliaus kalbẻjo: beje, kad su tavimi ir mirti turèčiau, ne norèčiau tavęs užsiginti. Lyg taipojau ir visi kalbejo.

32 Ir jie atèjo pas dvara, Getsẽmane vadinamą. Ir jis taré savo mokịtiniams: pasisėskite čia, iki nuejęs pasimelsu.

33 Ir drauge èmęs Petrą ir Jokubą ir Joną, pradējo drebèti ir sielvartauti;

34 Ir tarè jiems: mano dušia smutna yra iki smerties; čionai pasilikę budékite.

35 Ir mažumą toliaus nuejjęs, puolè ant žemės, melsdamasi, jei galima butu, kad praeitu ta adyna,

36 Ir sakydamas: Aba, mano Téve! vislab tau yra galima; atimk tą kyliką nuog manęs, tačiau, ne ką aš, bet ką tu nori.

$37 \mathrm{Ir}$ atẻjęs rado juos bemiegančius. Ir tarè Petrui: Simone, ar miegi? ar ne gali ben vieną adyną budèti?

38 Budèkite ir melskitès, kad ne ipultumbite i pagundymą. Dvasè yra noringa, bet kunas silpnas.

39 Ir vèl nuejjęs meldèsi, tus pačius žodžius kalbèdamas.

40 Ir sugrịžęs rado juos vèl bemiegančius, (nėsa ju akys pilnos buvo miego,) ir ne žinojo, ką jam atsakyti.

$41 \mathrm{Ir}$ atèjęs trečią kartą tarẻ jiems: Ak! argi dabar miegosite ir ilsẻsitẻs? gana, adyna atẻjo. 
St. MARK, XIV.

enough, the hour is come; behold, the Son of man is betrayed into the hands of sinners.

42 Rise up, let us go; lo, he that betrayeth $m e$ is at hand.

43 I And immediately, while he yet spake, cometh Judas, one of the twelve, and with him a great multitude with swords and staves, from the chief priests and the scribes and the elders.

44 And he that betrayed him had given them a token, saying, Whomsoever I shall kiss, that same is he; take him, and lead him away safely.

45 And as soon as he was come, he goeth straightway to him, and saith, Master, master; and kissed him.

46 If And they laid their hands on him, and took him.

47 And one of them that stood by drew a sword, and smote a servant of the high priest, and cut off his ear.

48 And Jesus answered and said unto them, Are ye come out, as against a thief, with swords and with staves to take me?

49 I was daily with you in the temple teaching, and ye took me not: but the scriptures must be fulfilled.

50 And they all forsook him, and fled.

51 And there followed him a certain young man, having a linen cloth cast about his naked body; and the young men laid hold on him :

52 And he left the linen cloth, and fled from them naked.

53 I And they led Jesus away to the high priest: and with him
EV. MARKOŠIAUS, XIV.

Štai, žmogaus sunus paduodamas

i griekininku rankas.

42 Kelkitès, eikime! štai, pašalyje mano išdavèjas.

43 Ir tuojaus, jam dar bekalbant, atèjo Judošius, vienas iš anul dvylika, ir su juomi didis pulkas su kardais ir su kartimis, nuo vyriausiujju kunigu, nuo raštemokitujju ir vyresniujju.

44 Ir išdavèjas buvo jiems ženklą davęs, sakydamas: kuri aš pabučiuosu, tas tikrasis; tą sugavę veskite tvirtai.

45 Ir atèjęs, tuojaus ji priẻjo ir tarè jam: Mokįtojau! Mokitojau! ir pabučiavo ji.

460 anie ji rankomis nutverdami sugavo.

47 Bet vienas tụ, kurie čia šale stovẻjo, ištraukęs savo kardą, ištiko vyriausiojo kunigo berną ir nukirto jo ausi.

48 Ir Jèzus atsakydamas tarè jiems: jus išẻjote, kaip ant kokio razbaininko, su kardais ir kartimis mane sugauti;

49 Aš kas dieną pas jus bažnyčioje buvau ir mokinau, o jus manęs ne gaudète. Bet kad raštas išsipildytų.

50 Ir visi mokitiniai ji palike pabėgo.

51 Ir buvo vienas jaunikaitis, tas sekė $\mathrm{ji}$, tas buvo drobe apvilktas ant nuogo kuno; ir jaunikaičiai tą sugavo.

52 Bet jis palikęs drobę, nuogas nuog ju pabẻgo.

53 Ir jie nuvedè Jèzụ pas vyriausiajji kuniga, kur susièję buvo visi 
ST. MARK, XIV.

were assembled all the chief priests and the elders and the scribes.

54 And Peter followed him afar off, even into the palace of the high priest: and he sat with the servants, and warmed himself at the fire.

55 And the chief priests and all the council sought for witness against Jesus to put him to death; and found none.

56 For many bare false witness against him, but their witness agreed not together.

57 And there arose certain, and bare false witness against him, saying,

58 We heard him say, I will destroy this temple that is made with hands, and within three days I will build another made without hands.

59 But neither so did their wit. ness agree together.

60 And the high priest stood up in the midst, and asked Jesus, saying, Answerest thou nothing? what is it which these witness against thee?

61 But he held his peace, and answered nothing. Again the high priest asked him, and said unto him, Art thou the Christ, the Son of the Blessed?

62 And Jesus said, I am : and ye shall see the Son of man sitting on the right hand of power, and coming in the clouds of heaven.

63 Then the high priest rent his clothes, and saith, What need we any further witnesses?

$64 \mathrm{Ye}$ have heard the blas-
EV. MARKOŠIAUS, XIV.

vyriausieji kunigai ir vyresnieji ir raštemokịtieji.

540 Petras iš tolo ji seké, iki i paločiu vyriausiojo kunigo; ir jis čia budamas sẻdèjo su tarnais ir šildèsi prie ugnies.

55 Bet vyriausieji kunigai ir visa rota jēškojo liudijimo prieš Jèzų, kad jam gala darytu; ir nieko ne rado.

56 Daug liudijo neteisiai prieš ji, bet jụ liudijimai ne sutarè.

57 Ir kiti atsikèlę neteisiai liudijo prieš ji, sakydami:

$58 \mathrm{Mes}$ girdejjome ji kalbant: aš noru bažnyčią, rankomis padarytają, pargriauti, ir i tris dienas kita pakurti, kuri ne rankomis pakurta.

59 Bet ju liudijimas dar ne sutarè.

60 Ir vyriausiasis kunigas kèlęsi tarp jų, klausė Jèzu, tarydamas: argi nieko ne atsakai ant to, ka tie liudija prieš tavę?

61 Bet jis tylëjo ir nieko ne atsakè. Tai ji vèl klausè vyriausiasis kunigas, jam sakydamas: ar tu esi Kristus, Sunus aukštai Pašlovintojo?

62 Bet Jèzus tarè: Aš esmi. Ir jus regésite žmogaus sunų sẻdintị po dešinès rankos stiprybès ir ateinant su dangaus debesimis.

63 Tai vyriausiasis kunigas, sudraskęs savo sermėgą, tarè: kogi be reikia mums daugiaus liudininku?

64 Girdejote tą Dievo bluznijimą. 
ST. MARK, XIV. XV.

phemy: what think ye? And they all condemned him to be guilty of death.

65 And some began to spit on him, and to cover his face, and to buffet him, and to say unto him, Prophesy : and the servants did strike him with the palms of their hands.

66 I And as Peter was beneath in the palace, there cometh one of the maids of the high priest:

67 And when she saw Peter warming himself, she looked upon him, and said, And thou also wast with Jesus of Nazareth.

68 But he denied, saying, I know not, neither understand I what thou sayest. And he went out into the porch; and the cock crew.

69 And a maid saw him again, and began to say to them that stood by, This is one of them.

70 And he denied it again. And a little after, they that stood by said again to Peter, Surely thou art one of them : for thou art a Galilæan, and thy speech agreeth thereto.

71 But he began to curse and to swear, saying, I know not this man of whom ye speak.

72 And the second time the cock crew. And Peter called to mind the word that Jesus said unto lim, Before the cock crow twice, thou shalt deny me thrice. And when he thought thereon, he wept.

\section{CHAPTER XV.}

ND straightway in the morn$A$ ing the chief priests held a censultation with the elders and
EV. MARKOŠIAUS, XIV. XV.

Kas jums regisi: bet jie visi ji prasudijo, ji verta esanti mirties.

65 Tai pradejjo keli i ji spiaudyti ir uždengti jo veidą ir kumsčiomis mušti ir jam sakyti: prarakauk mums. Ir bernai ištiko ji i veidą.

66 Ir Petras buvo žemai paločiuje; tai atèjo vyriausiojo kuniggo mergu viena;

67 Ir išvydusi Petrą besišildant, pažiurejjusi $i \mathrm{ji}$, tarè: $o$ ir tu taipjau buvai su tuom Jèzumi iš $\mathrm{Na-}$ zaret.

68 Bet jis užsigynë; tarydamas: aš jo ne pažịstu, neigi žinau, ką tu kalbi. Ir išejo laukan i pryangę, ir gaidys pragydo.

69 Ir merga išvydusi ji, vèl pradejjo sakyti čia stovintiemsiems: tas vienas yra tuju.

70 Ir jis vèl užsigynė. Ir po mažos valandos vẻl sakè Petrui tie, kurie čia stovẻjo: iš tiesos tu esi tuju vienas; nèsa tu esi Galilèiškis, ir tavo kalba tokiajau yra.

71 Bet jis pradejjo keiktis ir bažytis: aš ne pažistu to žmogaus, apie kuri kalbate.

72 Ir gaidys antrą kartą pragydo. Tai atsiminè Petras ano žodžio, kuri Jèzus jam buvo kalbẻjęs: gaidžiui dar ne du kartu pragydus, tu tris kartus manęs užsigịsi. Ir jis pradejjo verkti.

\section{PERSKYRIMAS XV.}

TR tuojaus ryto metą sudumė vyriausieji kunigai su vyresniaisiais ir raštemokịtaisiais, priegtam 
scribes and the whole council, and bound Jesus, and carried him away, and delivered him to Pilate. 2 And Pilate asked him, Art thou the King of the Jews? And he answering said unto him, Thou sayest it.

3 And the chief priests accused him of many things: but he an. swered nothing.

4 And Pilate asked him again, saying, Answerest thou nothing? behold how many things they witness against thee.

5 But Jesus yet answered nothing; so that Pilate marvelled.

6 Now at that feast he released unto them one prisoner, whomsoever they desired.

7 And there was one named Barabbas, which lay bound with them that had made insurrection with him, who had committed murder in the insurrection.

8 And the multitude crying aloud began to desire him to do as he had ever done unto them.

9 But Pilate answered them, saying, Will ye that I release unto you the King of the Jews?

10 For he knew that the chief priests had delivered him for envy.

11 But the chief priests moved the people, that he should rather release Barabbas unto them.

12 And Pilate answered and said again unto them, What will ye then that I shall do unto him whom ye call the King of the Jews?

13 And they cried out again, Crucify him.

14 Then Pilate saith unto them, ir visa rota, ir surišę Jèzų nuvedè, ir padavè ji Pilotui.

2 Ir Pilotas jo klausè: ar tu esi Žydu karalius? bet jis atsakydamas tarè jam: tu sakai.

3 Ir vyriausieji kunigai didei ji kaltino.

40 Pilotas jo vèl klausè, sakydamas: ar nieko ne atsakai? štai, kaip didei jie tavę apskundžia!

5 Bet Jèzus daugiaus nieko ne atsakè, aža ir Pilotas dyvijosi.

6 Bet jis papratęs buvo, jiems per velykų šventę vieną kalinị išleisti, kurio jie noréjo.

7 Ir buvo vienas, Barabošius vadinamas, sugautas su maištininkais, kurie maište razbajų buvo padarę.

8 Ir užẻję žmonès, prašè, kad darytu, kaip darydavo.

9 Bet Pilotas jiems atsakè: ar norite, kad jums Žydų karaliu išleisčiau?

10 Nès jis žinojo, vyriausiuosius kunigus $\mathrm{ji}$ iš pavydo išdavus.

11 Bet vyriausieji kunigai pakusè žmones, kad jiems veikiaus Barabošių išleistų.

12 Ir Pilotas vẻl atsakydamas tarè jiems: kogi norite, kad aš daryčiau tam, kurị vadinate karaliumi?

13 Jie vèl šaukè: nukryžiavok ji! 14 Bet Pilotas tarẻ jiems: kągi 
ST. MARK, XV.

Why, what evil hath he done? And they cried out the more exceedingly, Crucify him.

15 If And so Pilate, willing to content the people, released Baratbas unto them, and delivered Jesus, when he had scourged him, to be crucified.

16 And the soldiers led him away into the hall, called Prætorium; and they call together the whole band.

17 And they clothed him with purple, and platted a crown of thorns, and put it about his head,

18 And began to salute him, Hail, King of the Jews!

19 And they smote him on the head with a reed, and did spit upon him, and bowing their knees worshipped him.

20 And when they had mocked him, they took off the purple from him, and put his own clothes on him, and led him out to crucify him.

21 And they compel one Simon a Cyrenian, who passed by, coming out of the country, the father of Alexander and Rufus, to bear his cross.

22 And they bring him unto the place Golgotha, which is, being interpreted, The place of a skull. 23 And they gave him to drink wine mingled with myrrh : but he received it not.

24 And when they had crucified him, they parted his garments, casting lots upon them, what every man should take.

25 And it was the third hour, and they crucified him.

26 And the superscription of his

\section{EV. MARKOŠIAUS, XV.}

jis pikto padarẻ? bet jie dar juo daugiaus šaukè: nukryžiarok ji.

15 Tai Pilotas, norẻdamas žmonèms itikti, išleido jiems Barabošių; ir Jèzu jiems padavè, kad buty nuplaktas ir nukryžiavotas.

16 Bet kareiviai ivedè ji $\mathfrak{i}$ sudo butą, ir suvadino visą pulką.

17 Ir apsiautė ji purpura, ir nupynę erškèčiu vainiką, jam tą uždèjo;

18 Ir pradejjo ji sveikinti: sveiks, Žydu karaliau!

19 Ir mušè jo galvą nendre, ir spiaudè $\mathrm{i}$ ji, ir parsiklaupę meldèsi jo.

20 Ir kaip ji buvo apjuoke, nusiautè jo purpurą, ir aprẻdè ji jo paties rubais, ir išvedè $\mathrm{ji}, \mathrm{kad} j \mathrm{ji}$ nukryžiavotų.

21 Ir privertè vieną pro šali einantị, vardu Simona iš Cyrẻnios, kurs nuo lauko parèjo, (tèvą Aleksandro bei Rupo,) kad jam kryžiu neštų.

22 Ir jie nuvedè ji ant vietos Golgata, tai musų žodžiais: lavongalvių vieta.

23 Ir davė jam myra su vynu gerti, ir jis ne prièmè tai.

24 Ir kaip ji buvo nukryžiavoję, dalijosi jo rubus, mesdami ant ju burtą, kas ką gausiąs.

250 buvo apie trečią adyną, kaip ji kryžiarojo.

26 Ir buvo viršuje jo užrašyta, 
Sr. MARK, XV.

accusation was written over, THE KING OF THE JEWS.

27 And with him they crucify two thieves; the one on his right hand, and the other on his left.

28 And the scripture was fulfilled, which saith, And he was numbered with the transgressors.

29 And they that passed by railed on him, wagging their heads, and saying, Ah, thou that destroyest the temple, and buildest it in three days,

30 Save thyself, and come down from the cross.

31 Likewise also the chief priests mocking said among themselves with the scribes, $\mathrm{He}$ saved others; himself he cannot save.

32 Let Christ the King of Israel descend now from the cross, that we may see and believe. And they that were crucified with him reviled him.

33 And when the sixth hour was come, there was darkness over the whole land until the ninth hour. 34 And at the ninth hour Jesus cried with a loud voice, saying, Eloi, Eloi, lama sabachthani? which is, being interpreted, $\mathrm{My}$ God, my God, why hast thou forsaken me?

35 And some of them that stood by, when they heard it, said, Behold, he calleth Elias.

36 And one ran and filled a spunge full of vinegar, and put it on a reed, and gave him to drink, saying, Let alone; let us see whether Elias will come to take him down.

37 And Jesus cried with a loud voice, and gave up the ghost.
EV. MARKOŠIAUS, XV.

ko ji kaltino, butent: Žydu karalius.

27 Ir nukryžiavojo draug su juo$\mathrm{mi} d u$ razbaininku, vieną po jo dešinès, antrąji po kairès.

28 Tai išsipildè raštas, kursai sako: Jis yra tarp piktadejju parokuotas.

29 Ir kurie pro šali èjo, bluznijo ji, ir kratydami savo galvas, tarè: ben gèdėkis, kaip gražiai tu suardai bažnyčią ir pakuri ją $\mathfrak{i}$ tris dienas!

30 Pats dabar gelbėkis ir nužengk nuo kryžiaus.

31 Taipojau ir vyresnieji kunigai apjuokẻ ji tarp savęs su raštemokitaisiais, tarydami: kitus jis gelbejo, ir pats savę gelbètis ne gal. 32 Jei jis Kristus bei karalius Izraèlio, tai jis dabar nuo kryžiaus te nužengie, kad regètumbim ir tikètumbim. Ir tuodu, kuriuodu su juomi buvo nukryžiavotu, taipojau ji apjuokè.

33 Ir po šeštosios adynos radosi tamsybè per visą žemę, iki devintosios adynos.

34 Ir apie devintąja adyną šaukẻ Jèzus didžiu balsu, tarydamas: Eli, Eli, lama azabtani? tai yra musų žodžiais: mans Dieve, mans Dieve, kodèl manę prastojai?

35 Ir keli ten stovinčiųjų, tai išgirdę, sakẻ: štai, tas Eliošių vadina.

36 Tai bègęs viens pripildè kempinị uksosu, ir tą užmoręs ant nendrẻs, girdè ji sakydamas: palaukit, žiurẻkime, bau ateis Eliošius, ji nuimti.

37 Bet Jèzus šaukdamas didžiu balsu, išleido dvasę. 
ST. MARK, XV.

38 And the veil of the temple was rent in twain from the top to the bottom.

39 Il And when the centurion, which stood over against him, saw that he so cried out, and gave up the ghost, he said, Truly this man was the Son of God.

40 There were also women looking on afar off : among whom was Mary Magdalene, and Mary the mother of James the less and of Joses, and Salome;

41 (Who also, when he was in Galilee, followed him, and ministered unto him;) and many other women which came up with him unto Jerusalem.

42 I And now when the even was come, because it was the pre. paration, that is, the day before the sabbath,

43 Joseph of Arimathæa, an honourable counsellor, which also waited for the kingdom of God, came, and went in boldly unto Pilate, and craved the body of Jesus.

44 And Pilate marvelled if he were already dead: and calling unto him the centurion, he asked him whether he had been any while dead.

45 And when he knew it of the centurion, he gave the body to Joseph.

46 And he bought fine linen, and took him down, and wrapped him in the linen, and laid him in a sepulchre which was hewn out of a rock, and rolled a stone unto the door of the sepulchre.

47 And Mary Magdalene and Mary the mother of Joses beheld where he was laid.
EV. MARKOŠLAUS, XV.

38 Ir bažnyčios apkaba pusiau perdrisko i dvi dali, nuo viršaus iki apačios.

39 Bet kareiviu vyresnysis, kursai čia stovejjo ties juomi, regédamas, ji su tokiu šauksmu dvasę išleidžiant, sakè: iš tiesos, tas žmogus Dievo sunus buvęs.

40 Buvo taipojau ir moteru čionai, iš tolo tai žiurinčių, tarp kuriu buvo Marija Madlyna, ir Marija, mažojo Jokubo ir Juozèpo motyna, ir Salomé;

41 Kurios taipjau ji sekẻ, jam dar Galilèoje esant, ir jam tarnavo, ir daug kitu, kurios su juomi drauge užéjusios buvo i Jẻruzalę.

42 Ir vakare, kadangi diena buvo prigatavijimo, kurs yra šventas vakaras pirm sabatos,

43 Atẻjo Juozèpas iš Arimatios, viežlybas rotponis, kursai taipojau karalystès Dievo laukè; tasai pasidrąsinęs ir iejjęs pas Pilotą, prašè Jėzaus lavono.

44 Bet Pilotas dyvijos, kad jis jau buvo numiręs, ir pasivadinęs kareiviu vyresniji, klause jo: ar jis seniai numiręs?

45 Ir ištyręs nuo kareiviu vyresniojo, davè Juozẻpui lavoną.

$46 \mathrm{Ir}$ jis nusipirkęs drobę, ir nuèmęs ji, isiautè $\dot{i}$ drobę ir paguldè ji i kapa, tasai buvo i uolą ikaltas, ir užrito akmeni už kapo angos.

47 Bet Marija Madlyna ir Marija Jozẻs pažiurèjo, kur jis buvo padètas. 
ST. MARK, XVI.

\section{CHAPTER XVI.}

ND when the sabbath was A past, Mary Magdalene, and Mary the mother of James, and Salome, had bought sweet spices, that they might come and anoint him.

2 And very early in the morning the first day of the week, they came unto the sepulchre at the rising of the sun.

3 And they said among themselves, Who shall roll us away the stone from the door of the sepulchre?

4 And when they looked, they saw that the stone was rolled away: for it was very great.

5 And entering into the sepulchre, they saw a young man sitting on the right side, clothed in a long white garment; and they were affrighted.

6 And he saith unto them, Be not affrighted: Ye seek Jesus of Nazareth, which was crucified : he is risen; he is not here : behold the place where they laid him.

7 But go your way, tell his disciples and Peter that he goeth before you into Galilee : there shall ye see him, as he said unto you.

8 And they went out quickly, and fled from the sepulchre; for they trembled and were amazed: neither said they any thing to any man; for they were afraid.

9 I Now when Jesus was risen early the first day of the week, he appeared first to Mary Magdalene, out of whom he had cast seven devils.

10 And she went and told them
EV. MARKOŠIAUS, XVI.

\section{PERSKYRIMAS XVI.}

TR sabatai perẻjus, pirkosi Marija Madlyna ir Marija Jokubo ir Salomė žolių, gražiai kvepiančių, kad atẻjusios ji mostytų.

2 Ir labai anksti pirmoje dienoje sabatu atejo jos pas kapą, saulei užtekant.

3 Ir kalbẻjo tarp savęs: kas mums atris akmeni nuo kapo angos?

4 Ir nužiurèdamos ten, išvydo akmeni atristą; nẻs buvo labai didis.

5 Ir i̇ejjusios i kapą, išvydo jaunikaiti sèdint po dešinès, apvilkta. baltu rubu, ir jos nusigando.

6 Bet jis sake joms: ne nusigąskite; Jẻzaus jus jęškote iš $\mathrm{Na-}$ zaret, nukryžiavotojo; jis kèlès ir niera čia; štai vieta, kur ji padẻję buvo.

7 Bet nuejjusios pasakykite jo mokitiniams ir Petrui, kad jis pirm jųsu nueis i Galilèą tenai ji matysite, kaip jis jums sakęs.

$8 \mathrm{Ir}$ išejusios veikiai pabẻgo nuo kapo; nẻsa apėmęs jas buvo drebèjimas ir išgąstis, ir niekam nieko ne sakẻ. nès bijojos.

9 Bet Jèzus iš numirusiuju prisikẻlęs anksti pirmoje dienoje sabatu, pirmiaus pasirodè Marijai Madlynai, iš kurios jis septynis velnius buvo išvaręs.

10 Ir ji nuejjusi, apsakẻ tai tiems, 
ST. MARK, XVI.

that had been with him; as they mourned and wept.

11 And they, when they had heard that he was alive, and had been seen of her, believed not.

12 I After that he appeared in another form unto two of them, as they walked, and went into the country.

13 And they went and told it unto the residue : neither believed they them.

14 I Afterward he appeared unto the eleven as they sat at meat, and upbraided them with their unbelief and hardness of heart, because they believed not them which had seen him after he was risen.

15 And he said unto them, Go ye into all the world, and preach the gospel to every creature.

$16 \mathrm{He}$ that believeth and is bap. tized shall be saved; but he that believeth not shall be damned.

17 And these signs shall follow them that believe: In my name shall they cast out devils; they shall speak with new tongues;

18 They shall take up serpents; and if they drink any deadly thing, it shall not hurt them; they shall lay hands on the sick, and they shall recover.

19 I So then after the Lord had spoken unto them, he was received up into heaven, and sat on the right hand of God.

20 And they went forth, and preached every where, the Lord working with them, and confirming the word with signs following. Amen.
EV. MARKOŠIAUS, XVI.

kurie su juomi budavo, kurie gedejjo ir verkè.

11 Ir tie, išgirdę ji gyvą esanti, ir jai pasirodžiusi, ne vierijo.

12 Potam, dviem iš jụ einant, pasirodè jis kitokiu veidu, kaip juodu ant lauko èjo.

13 Ir tuodu taipjau nuejusiu, apsake tai kitiems; bet ir tiemdviem jie ne vierijo.

14 Paskiaus, kaip anie vienuolika už stalo sẻdejjo, pasirodẻ jis jiems ir barė ju netikèjimą ir širdies kietuma, kad tiems ne buvo vierije, kurie ji regẻjo prisikèlusị.

15 Ir tarè jiems: Eikite i visą svietą ir sakykite èvangèlią visam sutvėrimui.

16 Kursai tik ir pakrikštytas yra, tas bus išganytas; bet kurs ne tik, tas bus pražudytas.

17 Bet ženklai, kurie seks tuos, kurie tik, yra tie: mano vardan velnius išvarys, naujais liežuviais kalbès,

18 Žalčius pravarys, ir norint ko smertiško gertu, jiems nieko nekenks; ant ligonių jie rankas uždès, tai jie geryn eis.

19 Ir Viešpats tai su jais kalbèjęs, pakeltas buvo ił dangu, ir sèd po dešinès Dievo.

20 Bet jie išèje apsakẻ Dievo žodị visose šalyse. Ir Viešpats jiems padejjo ir žodi pastiprino pasekančiais ženklais. 
Printed by Trowitzsch \& Son, Berlin. 



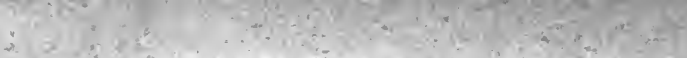

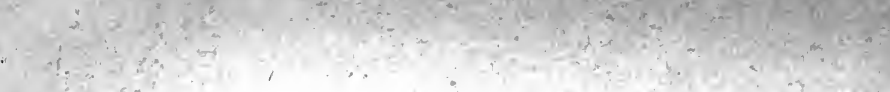

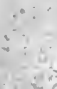

$\frac{1}{2}+\frac{2}{2}$

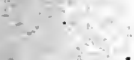

$a-15=$

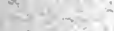

$\therefore \ldots+3$

$\sqrt{8}, \therefore$

an.

,, 1,

in

$+\frac{1}{3}$

$x^{-1}+2=$

(1.

$6 y^{2}=2 x+4$

- ia

$6 y^{2}$

$\therefore$

,

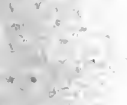

sit

•

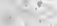

is 0

$\left.-\frac{1}{4}\right)^{\prime}$

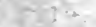

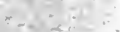

$7 x$

$\therefore-$

$\therefore 6=$

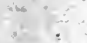

$+1$.

$x^{2}, 8^{2}, x^{3}$

$\because 11=$

$\therefore$

$\therefore \therefore-1$

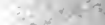

$4 y^{2}+x^{2}=$

$\therefore a^{2}+x^{2}$

$\cdots, y^{2}+y^{4}=$

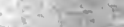

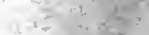

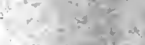

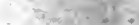

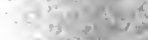

$\because 3+2=0$

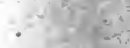

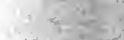

?. $2 x^{2}=x^{2}$

$3+13010$

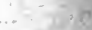

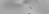

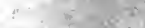

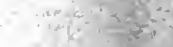

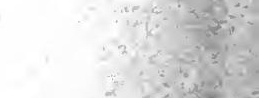

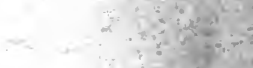
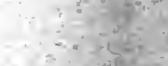

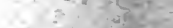
$=3^{2}, x+2=$

$3012=21$

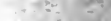

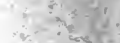

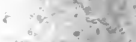

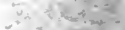

$=76 \times x^{2}=$

$0 x^{2}+x^{2}$

$1=-3=2 x+4$

$+4 x^{2}+3 x^{3}+3=$

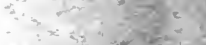

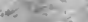

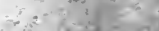

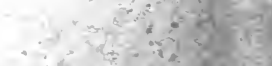

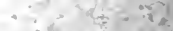

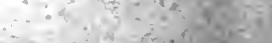

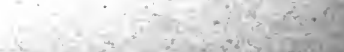




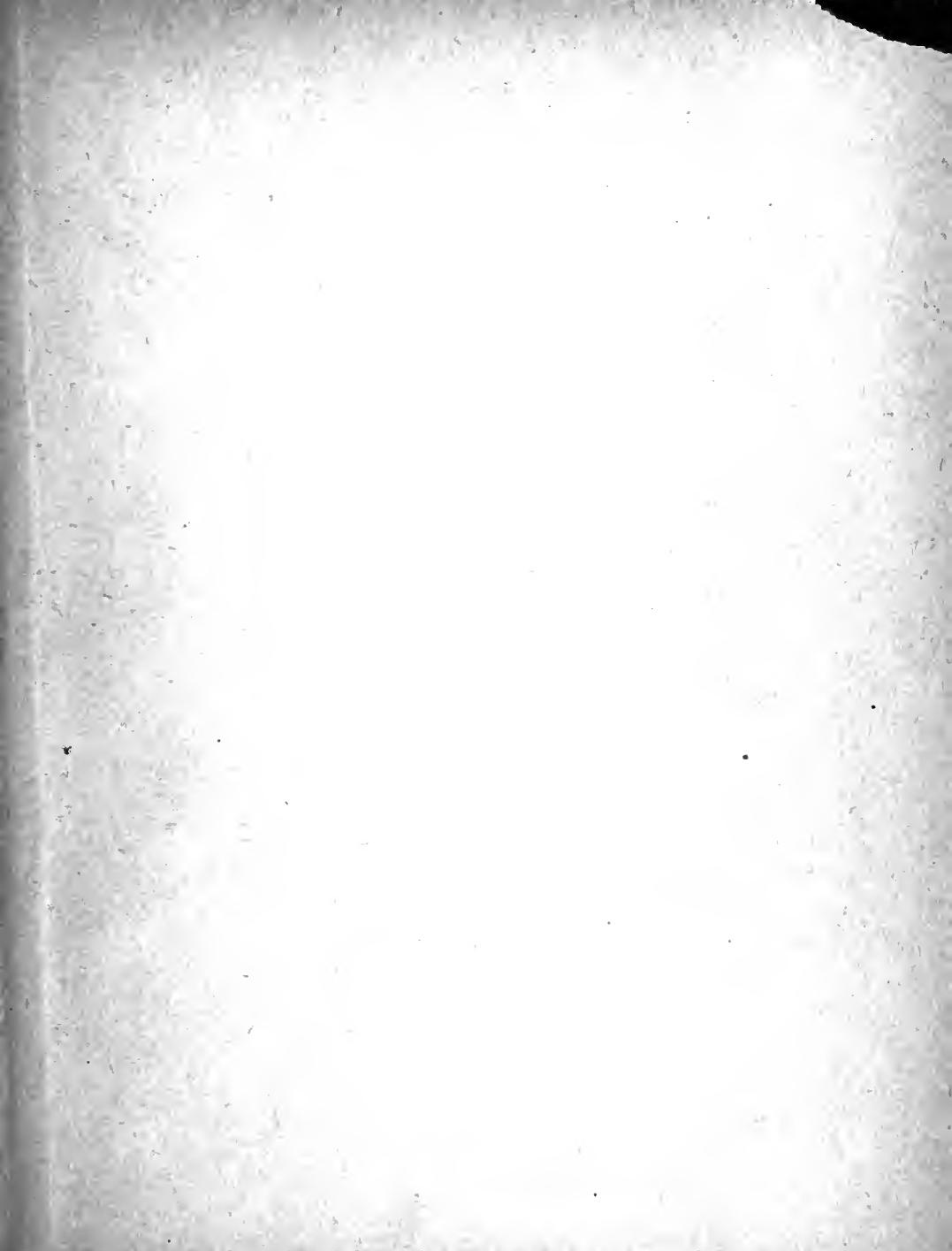


RETURN TO the circulation desk of any

University of California Library

or to the

NORTHERN REGIONAL LIBRARY FACILITY

Bldg. 400, Richmond Field Station

University of California

Richmond, CA 94804-4698

ALL BOOKS MAY BE RECALLED AFTER 7 DAYS

2-month loans may be renewed by calling

(510) 642-6753

1 -year loans may be recharged by bringing books to NRLF

Renewals and recharges may be made 4 days prior to due date

\section{DUE AS STAMPED BELOW}

\section{JUL $3-1996$}

\section{JUN 121998}




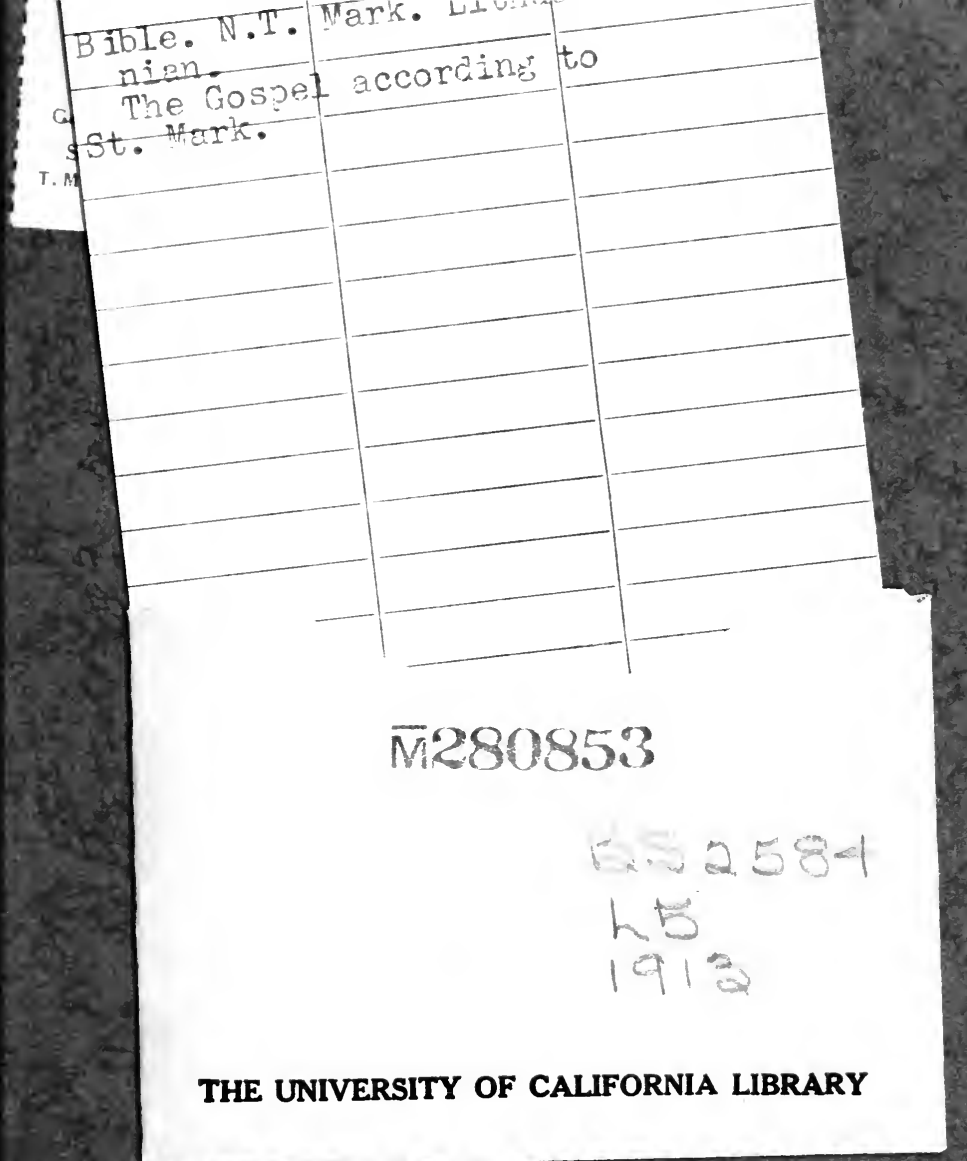




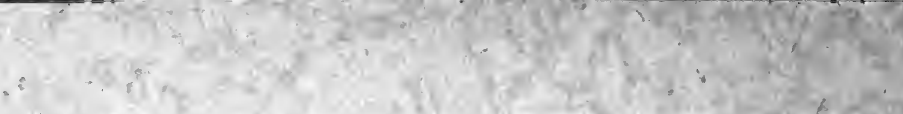

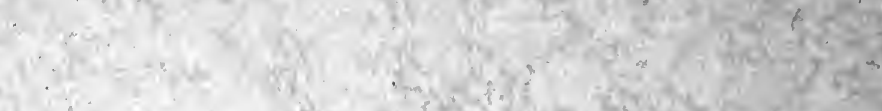

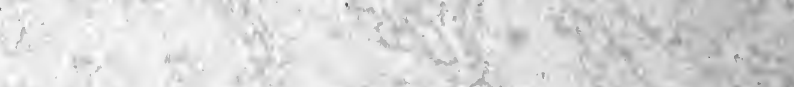

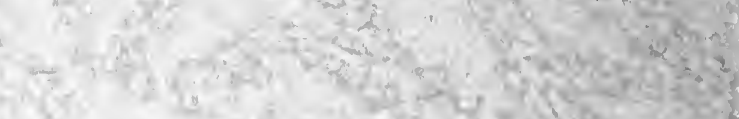

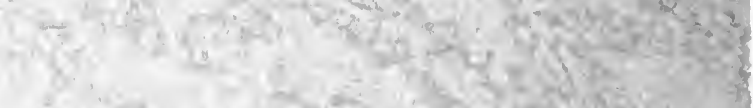
rand act as

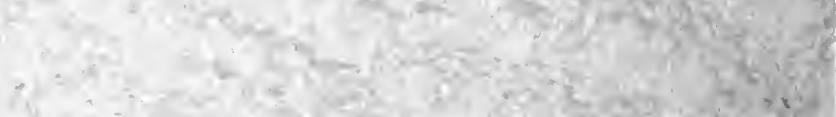

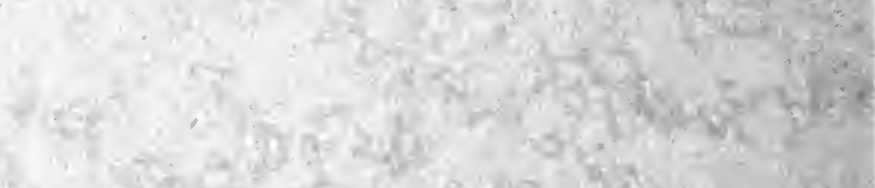

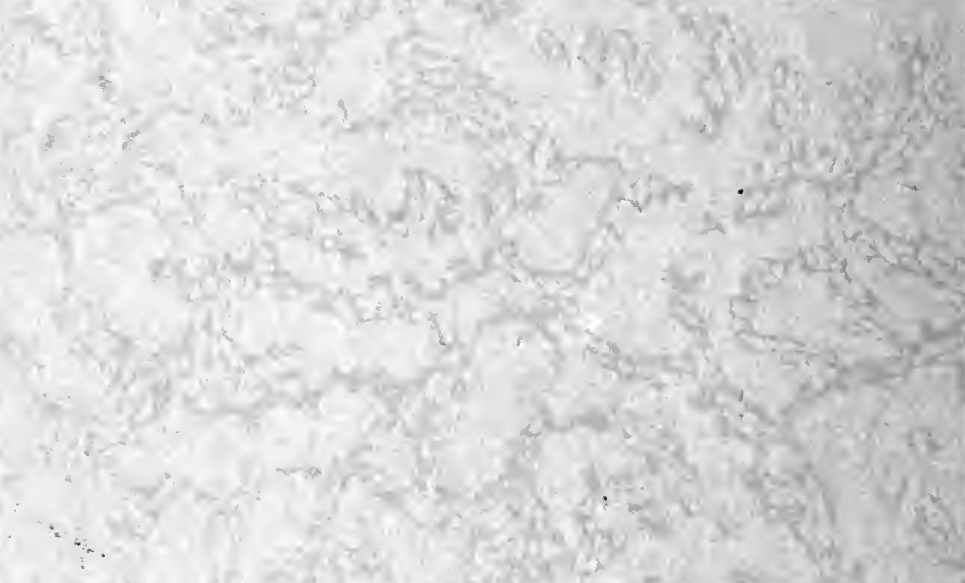

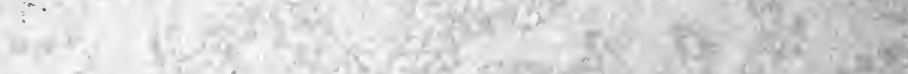
(1) 